\title{
CRESCIMENTO, CARACTERÍSTICAS FÍSICAS E ANATÔMICAS DA MADEIRA JUVENIL DE DOIS CLONES DE Eucalyptus grandis Hill ex Maiden EM RESPOSTA À APLICAÇÃO DE BORO
}

\author{
JULIANA APARECIDA BOUCHARDET \\ Engenheiro Florestal
}

Orientador: Prof. Dr. HILTON THADEU Z. DO COUTO

Dissertação apresentada à Escola Superior de Agricultura "Luiz de Queiroz", Universidade de São Paulo, para obtenção do título de Mestre em Recursos Florestais, Área de Concentração: Recursos Florestais, com opção em Manejo de Florestas de Produção.

PIRACICABA

Estado de São Paulo - Brasil

Março - 2002 


\section{ERRATA}

Página 21 - 3.4 Análise estatística: não foi feita a análise "Dose de boro $x$ concentração de macro e micronutrientes nas folhas".

Página $24-5^{\circ}$ parágrafo, $2^{\circ}$ linha: onde se lê "ao $5^{\mathrm{a}}$ e $6^{\mathrm{a}}$ pares de folhas", leia-se "à $5^{\text {a }}$ e $6^{\text {a }}$ folhas".

Página 31 - Figura 4 - C: onde se lê "Seca de ponteiro e bifurcação do tronco no clone A2", leia-se "Bifurcação do tronco no clone A2".

Página 46 - Figura 9 - B: apresenta erro no título do eixo $x$, onde se lê "Dose de $B$ ( $\left.\mathrm{mg} \mathrm{kg}^{-1}\right)$ ", leia-se "Dose de B (kg ha-1)". 


\title{
Dados Internacionais de Catalogaçāo na Publicação (CIP) DIVISĀO DE BIBLIOTECA E DOCUMENTAÇÃO - ESALQ/USP
}

\author{
Bouchardet, Juliana Aparecida \\ Crescimento, características fisicas e anatômicas da madeira juvenil de dois clones \\ de Eucalyptus grandis Hill ex Maiden em resposta à aplicação de boro / Juliana \\ Aparecida Bouchardet. - - Piracicaba, 2002. \\ $69 \mathrm{p}$. \\ Dissertação (mestrado) - Escola Superior de Agricultura Luiz de Queiroz, 2002. \\ Bibliografia.
}

1. Boro 2. Clonagem 3. Eucalipto 4. Madeira 5. Propriedade 1. Título

CDD 674.142

Sermitida a copia total ou parcial deste documento. desde que citada a fonte 0 autor 
Aos meus pais Newton, Maria de Lourdes e ao meu irmão José Augusto, pelo amor, compreensão e incentivo durante o desenvolvimento deste trabalho.

\section{DEDICO}




\section{AGRADECIMENTOS}

Ao Prof. Dr. Hilton Thadeu Zarate do Couto pela orientação e amizade durante o desenvolvimento deste trabalho.

Ao Eng. Florestal Ronaldo Luiz Vaz de Arruda Silveira pela amizade, incentivo, sugestões e críticas ao trabalho.

Ao Prof. Dr. Antônio Natal Gonçalves pela amizade e sugestões durante a realização do trabalho.

À Cia. Suzano de Papel e Celulose, na pessoa do Eng $^{\circ}$ Florestal José Luís Gava, pelo suporte técnico para realização do trabalho.

Ao Prof. Dr. Francides Gomes da Silva, Regina Buch e Udemilson Cerebelli, do Departamento de Ciências Florestais, pelo auxílio na realização das análises das características da madeira.

Aos funcionários do Departamento de Ciências Florestais e IPEF, Jefferson Lordello Polizel (Lab. De Métodos Quantitativos), Ivo Rosa Filho (SAl) e Paulo Sérgio Beraldo (Biblioteca), por toda ajuda dispensada nas várias etapas dessa dissertação.

À Ana Gabriela (Bromélia) pela amizade, pelas longas horas de conversa e pela ajuda nos trabalhos de campo (o que nos faz lembrar do inesquecivel lanche de Itatinga....).

Ao Luis Francisco (Tódi) pela amizade e paciência em me escutar, o que acabou rendendo boas risadas (Eu consegui!!!!!).

Aos meus grandes amigos em especial: Marilia Cantarelli (Bronzina), Fabiane Ducatti (Neon), Alexandre Astorino (Sedex), Marcelo Cavalcanti (Pointer), Fabiano Rodrigues (Roko), Fábio Sgarbi, Edson Namita Higashi e Vanderlei Stefanuto por todos os momentos compartilhados durante a realização dessa dissertação.

À FAPESP pelo auxílio financeiro concedido. 


\section{SUMÁRIO}

Página

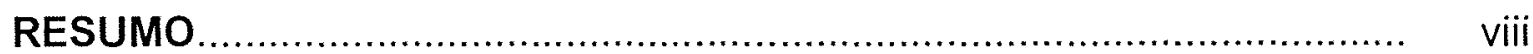

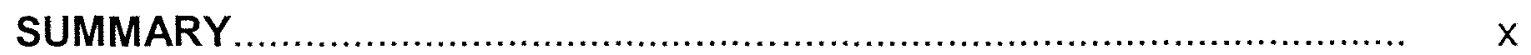

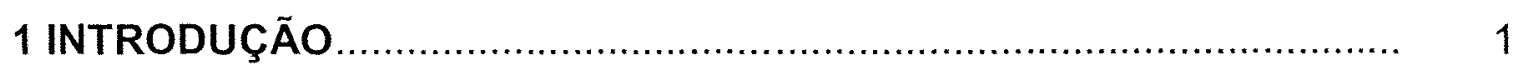

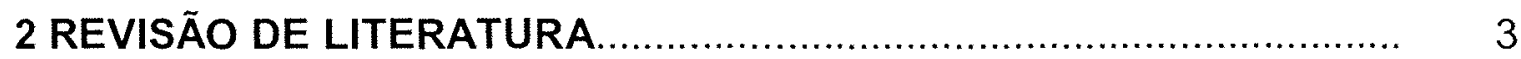

2.1 Funções do boro na planta............................................................... 3

2.2 Sintomas de deficiência de boro....................................................... 5

2.3 Faixas adequadas e deficientes dos nutrientes.................................. 8

2.4 Resposta do eucalipto à aplicação de boro.......................................... 9

2.5 Efeitos da adubação e do estado nutricional sobre as características físicas e anatômicas da madeira.............................................................. 13

2.6 O fenômeno da geada.................................................................. 17

3 MATERIAL E MÉTODOS............................................................ 20

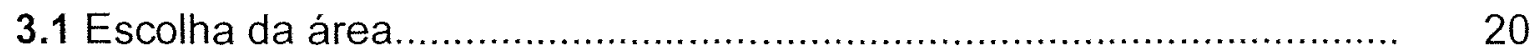

3.2 Material genético.................................................................. 20

3.3 Delineamento experimental....................................................... 20

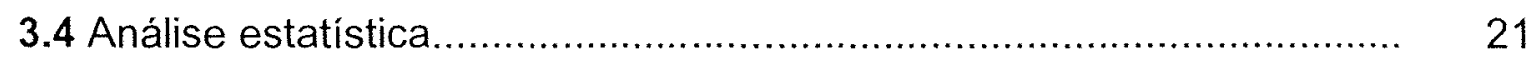

3.5 Amostragem de solo............................................................... 22

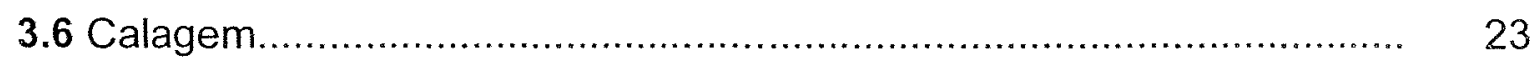

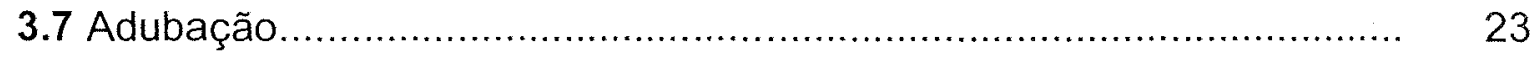

3.7.1 Adubação de plantio .................................................................... 23

3.7.2 Adubação de cobertura............................................................. 24

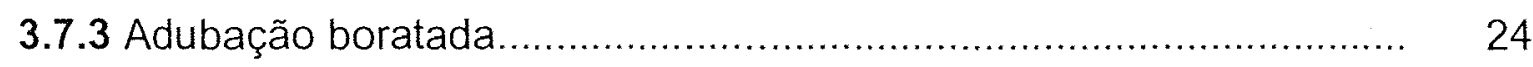


3.8 Avaliação, colheita e preparo do material vegetal para análise............. 24

3.9 Análise química do material vegetal................................................. 25

3.10 Avaliação do crescimento ............................................................. 26

3.11 Características da madeira.......................................................... 27

3.11.1 Análise anatômica................................................................... 27

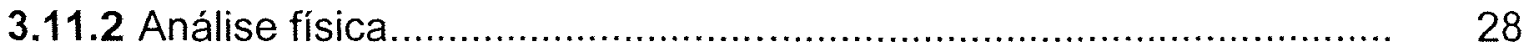

3.12 Avaliação da qualidade do fuste ....................................................... 29

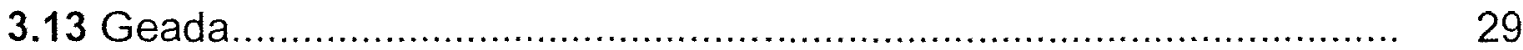

3.13.1 Avaliação dos danos causados pela geada.................................. 29

4 RESULTADOS E DISCUSSÃO ....................................................... 30

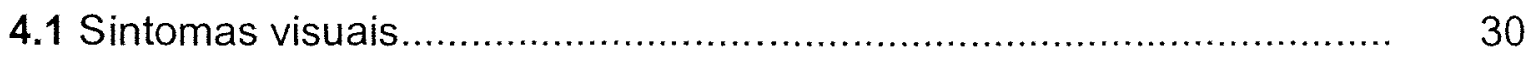

4.1.1 Deficiência de boro.................................................................... 30

4.2 Avaliação do crescimento das plantas................................................ 32

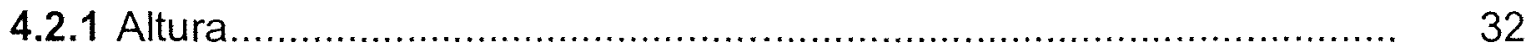

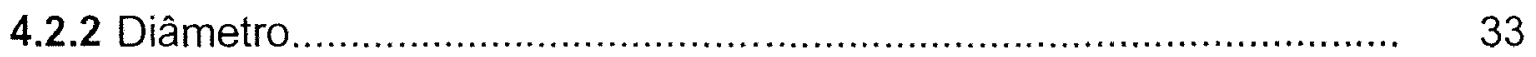

4.2.3 Volume cilíndrico de madeira ........................................................ 34

4.3 Estado nutricional dos clones de E. grandis.................................... 36

4.3.1 Efeito dos clones na concentração dos macronutrientes.................. 36

4.3.2 Efeito dos clones na concentração dos micronutrientes................... 40

4.3.3 Relação entre a dose de boro aplicada e a concentração nas folhas.

4.3.4 Relação entre concentração de boro nas folhas e o volume cilíndrico de madeira........................................................................... 47

4.4 Qualidade da madeira................................................................. 49

4.4.1 Densidade básica da madeira.................................................... 49

4.4.2 Parâmetros anatômicos: comprimento, largura, diâmetro do lume, espessura e fração parede.................................................................... 51

4.5 Resistência à geada........................................................................ 53

4.6 Qualidade do fuste ..................................................................... 55

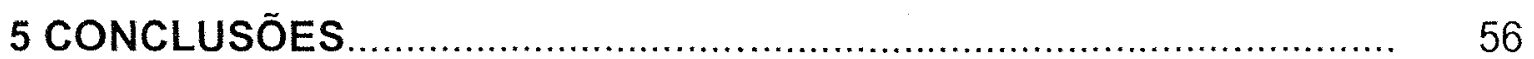




\title{
CRESCIMENTO, CARACTERÍSTICAS FÍSICAS E ANATÔMICAS DA MADEIRA JUVENIL DE DOIS CLONES DE Eucalyptus grandis Hill ex Maiden EM RESPOSTA À APLICAÇÃO DE BORO
}

\author{
Autora: JULIANA APARECIA BOUCHARDET \\ Orientador: Prof. Dr. HILTON THADEU Z. DO COUTO
}

\section{RESUMO}

O estudo teve por objetivo determinar os efeitos do boro sobre o crescimento e as características físicas e anatômicas da madeira juvenil de dois clones de E. grandis. Dois meses antes da instalação do experimento foi feita uma aplicação de calcário dolomítico em área total, na dosagem de $1,7 \mathrm{t} \mathrm{ha}^{-1}$. A adubação de plantio foi comum a todos os tratamentos e consistiu na aplicação de $90 \mathrm{~kg}$ de $\mathrm{P}_{2} \mathrm{O}_{5}$ ha $^{-1}$ na forma de superfosfato triplo. A adubação nitrogenada e potássica foi igual para todos os tratamentos, com as doses parceladas em duas aplicações. Aos 2 meses após o plantio, foram aplicados $20 \mathrm{~kg} \mathrm{~N} \mathrm{ha}^{-1}$ e 40 $\mathrm{kg} \mathrm{K}_{2} \mathrm{O}$ ha $^{-1}$, correspondente a $30 \%$ da dose total e os $70 \%$ restante foram aplicados aos 9 meses após o plantio com $40 \mathrm{~kg} \mathrm{~N} \mathrm{ha}^{-1}$ e $80 \mathrm{~kg} \mathrm{~K}_{2} \mathrm{O} \mathrm{ha}^{-1}$. As fontes utilizadas foram o sulfato de amônio e o cloreto de potássio. Juntamente com o nitrogênio e o potássio, aos 2 meses de idade, foram/aplicados $2 \mathrm{~kg}$ de 
Zn ha ${ }^{-1}$ e $1 \mathrm{~kg}$ de $\mathrm{Cu} \mathrm{ha}{ }^{-1}$ na forma de sulfato de zinco e sulfato de cobre, respectivamente. $\mathrm{O}$ boro foi aplicado juntamente com os adubos potássicos e nitrogenados, sendo $30 \%$ da dose total aplicada aos 2 meses após o plantio e os $70 \%$ restante aos 9 meses após o plantio. O produto utilizado como fonte de B foi o Bórax (11\% B) e as doses foram de 0;0,5; $1 ; 2 ; 4$ e $8 \mathrm{~kg} \mathrm{~B} \mathrm{ha}^{-1}$. Aos $12 \mathrm{e}$ 24 meses após o plantio, foi feita avaliação do estado nutricional das plantas através da coleta de três tipos de folhas (nova, velha e diagnóstico) de ramos situados na região mediana da copa das árvores. A avaliação do crescimento foi realizada aos 12 e 24 meses de idade. Aos 12 meses, foram medidos o DAP e a altura das 28 árvores úteis da parcela. Aos 24 meses, foram realizadas medições de DAP e altura somente de 10 árvores úteis de cada parcela. A seleção dessas árvores foi feita de maneira sistemática, procurando sempre evitar árvores atípicas ou defeituosas (bifurcadas, trifurcadas e retorcidas). De amostras contidas no lenho foram realizadas análises anatômicas para determinação do comprimento, largura, diâmetro do lume, espessura e fração parede. Determinou-se também a densidade básica da madeira na altura do DAP. Nas condições do experimento, as principais conclusões foram que os clones responderam de maneira diferenciada à aplicação de boro para a produção em volume de madeira, sendo que a aplicação de boro proporcionou maiores ganhos ao clone $A 1$, aos 12 e 24 meses de idade. A faixa adequada de boro nas folhas diagnóstico variou em função dos clones e da idade. O nivel

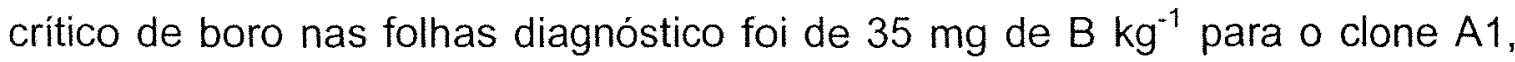
aos 12 meses de idade. Aos 24 meses de idade, o nível crítico para o clone A1 foi de $18 \mathrm{mg}$ de $B \mathrm{~kg}^{-1}$ e para o clone $\mathrm{A} 2$ foi de $16 \mathrm{mg}$ de $B \mathrm{~kg}^{-1}$. As doses de boro não tiveram efeito significativo sobre a densidade e as características anatômicas da madeira dos clones de E. grandis, aos 24 meses de idade. 


\title{
GROWTH, PHYSICAL AND ANATOMICAL CHARACTERISTICS OF THE TWO-CLONE JUVENILE WOOD OF Eucalyptus grandis Hill ex Maiden IN ANSWER TO BORON APLLICATION
}

\author{
Author: JULIANA APARECIDA BOUCHARDET \\ Adviser: Prof. Dr. HILTON THADEU ZARATE DO COUTO
}

\section{SUMMARY}

This study had the objective of determining boron effects over the growth and physical and anatomical characteristics of the two-clone juvenile wood of $E$. grandis. Two months before the experiment installation one application of dolomite calcarious was made in a total areas at a dosage of 1,7 $\mathrm{ha}^{-1}$. The plantation fertilization was common to all treatments and consisted of the application of $90 \mathrm{~kg}$ of $\mathrm{P}_{2} \mathrm{O}_{5} \mathrm{ha}^{-1}$ as of triple superphosphate. The nitrogen and potassium fertilization was equal for all treatments, with the doses divided into two applications. Two months immediately after the plantation were applied $20 \mathrm{~kg} \mathrm{~N} h a^{-1}$ and $40 \mathrm{~kg} \mathrm{~K}_{2} \mathrm{O}$ ha $^{-1}$ corresponding to $30 \%$ of the total dose and the $70 \%$ resting were applied to the nine months immediately after the plantation with $40 \mathrm{~kg} \mathrm{~N} \mathrm{ha}^{-1}$ and $80 \mathrm{~kg} \mathrm{~K}_{2} \mathrm{O} \mathrm{ha}{ }^{-1}$. The sources utilized were ammonia sulphate and potassium chloride. Among with nitrogen and potassium by the two months of age were applied $2 \mathrm{~kg}$ of $\mathrm{Zn} \mathrm{ha}{ }^{-1}$ and $1 \mathrm{~kg}$ of $\mathrm{Cu} \mathrm{ha} a^{-1}$ in the of zinc sulphate and copper sulphate, respectively. Boron was applied together with the potassium and nitrogen fertilization, being $30 \%$ at total applied 
dose by the two months immediately after the plantation and the $70 \%$ resting by the nine months immediately after the plantation. The product utilized as a source of boron was Bórax $(11 \% \mathrm{~B})$ and the doses were of $0 ; 0,5 ; 2 ; 4$ and $8 \mathrm{~kg}$ $\mathrm{B} \mathrm{ha}^{-1}$. By 12 and 24 months immediately after plantation, an evaluation was made for the nutritional state of the plants through a collect of three types of leaves (young, old and diagnostic) of branches in the medium region on the trees crown. The growth evaluation was accomplished by the 12 and 24 months of age. By 12 months DBH were measured and the height of 28 useful trees for each parcel. By 24 months DBH measures were held and height only for 10 useful trees for each parcel. The selection of these trees was made in a systematic way trying always avoiding atypic and defective trees. From the samples contained in the stem were made anatomical analyses for determining length, width, the diameter of the lumen, thickness and fiber's wall fraction. It was determined also basic density of the wood at DBH height. In the conditions of experiment, the main conclusions were that the clones corresponded in a differentiated way to boron application that supplied bigger gains at clone $A 1$, by 12 and 24 months of age. The appropriate range of boron in diagnostic leaves varied in function of clones and age. The critical level of boron in diagnostic leaves was of $35 \mathrm{mg}$ of $B \mathrm{~kg}^{-1}$ for clone $\mathrm{A} 1$, by the 12 months of age. By 24 months of age, the critical level for clone $A 1$ was of $18 \mathrm{mg}^{-} \mathrm{B} \mathrm{kg}^{-1}$ and for clone $\mathrm{A} 2$ was of $16 \mathrm{mg}$ of $\mathrm{B} \mathrm{kg}$. The doses of boron did not have significant effect over the density and anatomical characteristics of the clones wood of $E$. grandis, by 24 months of age. 


\section{INTRODUÇÃO}

O eucalipto, devido às características de rápido crescimento, produtividade, ampla diversidade de espécies, grande capacidade de adaptação e por ter seu uso destinado à diferentes finalidades, tem sido amplamente utilizado em plantações florestais.

As espécies de eucalipto são comumente plantadas para atender finalidades industriais, como madeira para serraria, postes, aglomerados e, principalmente para a produção de celulose. Pelas estimativas da Associação Brasileira de Celulose e Papel, o Brasil produziu no ano de 2000 o equivalente a 7.463.266 $\mathrm{t}$ de pasta celulósica, das quais 5.539.265 $\mathrm{t}$ de celulose de eucalipto. A área reflorestada que abastece esse setor é de 4.793 .000 ha, sendo que $62 \%$ dessa área é representada por espécies de eucalipto. A cultura do eucalipto ocupa uma área de 2.966 .780 ha, sendo que $51 \%$ e $19 \%$ dessa área se encontra no estado de Minas Gerais e São Paulo, respectivamente (BRACELPA, 2000).

Entre as espécies do gênero Eucalyptus a mais plantada é o E. grandis, sendo a mais utilizada no setor de papel e celulose, com um percentual de $50 \%$ em relação as demais espécies do gênero (ANFCP, 1996). Segundo Mora et al. (2000), o E. grandis possui excelentes qualidades, superando qualquer outra em incremento, quando as condições ambientais são favoráveis.

Entretanto, a grande maioria dos povoamentos florestais está sobre solos pobres, muito intemperizados e lixiviados, portanto, com baixa disponibilidade de nutrientes para as plantas. Como fator 
complicante, o suprimento da demanda nutricional das árvores é prejudicado pelos altos índices de deficiência hídrica que ocorrem na maior parte dessas áreas (Novelino et al., 1982; Gonçalves, 1995; Coutinho et al. 1995).

Entre os micronutrientes, o boro é um dos que apresenta níveis mais limitantes nos solos florestais. No Brasil, a ocorrência de deficiência de boro tem se intensificado à medida que os reflorestamentos avançam para áreas onde o regime de precipitação é geralmente caracterizado por um período de seca prolongada. Nesse período, a mineralização da matéria orgânica (principal fonte de boro) é menor, em razão da baixa atividade dos microorganismos, além de ocorrer uma menor absorção desse micronutriente o qual se dá por fluxo de massa (Balloni, 1977; Novelino et al. 1982; Malavolta \& Kliemann, 1985).

A grande maioria dos trabalhos disponiveis sobre fertilização em povoamentos florestais se preocupa basicamente em avaliar o seu efeito sobre a produção volumétrica (Barros et al., 1990). As pesquisas envolvendo o boro foram basicamente restritas ao seu efeito sobre o desenvolvimento e crescimento das árvores. Poucos estudos procuraram relacionar o boro com a qualidade da madeira, apesar de na literatura uma das funções a ele atribuída ser a formação da parede celular e a sintese de lignina e celulose (Malavolta et al., 1997a; Silveira, 1998; Lima Filho, 1998).

As hipóteses do trabalho foram: os clones respondem de forma diferenciada à aplicação de boro; o boro altera a características físicas e anatômicas da madeira juvenil dos clones.

O trabalho teve por objetivo determinar o efeito da adubação boratada no crescimento e nas características da madeira juvenil de dois clones de Eucalyptus grandis. 


\section{REVISÃO DE LITERATURA}

\subsection{Funções do boro na planta}

O boro é absorvido pelas plantas na forma de ácido bórico $\left(\mathrm{H}_{3} \mathrm{BO}_{3}\right.$ ou $\mathrm{H}_{2} \mathrm{BO}_{3}{ }^{-}$) não dissociado. Há dúvidas quanto ao processo de absorção, se passivo ou ativo. $O$ transporte das raízes à parte aérea ocorre de modo passivo sob forma inorgânica ou como complexos açúcar-borato, na corrente transpiratória. Admite-se, de modo geral, que é transportado somente no xilema, sendo praticamente imóvel no floema (Malavolta et al. 1997a). É o único nutriente que não satisfaz o critério direto da essencialidade, sendo que não se encontrou nenhum composto vital no qual ele participe e nem se identificou qualquer reação crucial para o metabolismo que é interrompida na sua ausência (Malavolta, 1980).

Ainda se sabe muito pouco sobre a função exata do boro no metabolismo das plantas (Matoh et al. 1992). Afirma-se que suas funções estão relacionadas ao transporte de açúcares das folhas para os demais órgãos da planta, formação da parede celular, divisão celular (formação de gemas apicais, axilares e radiculares), sintese de lignina e celulose, balanço hormonal (em tecidos carentes em $B$ acumula-se AIA), sintese de ácidos nucléicos e proteínas, metabolismo dos fenóis e absorção radicular (Pollard et al. 1977; Gupta, 1979; Malavolta, 1980; Malavolta et al., 1997a; Silveira, 1998; Lima Filho, 1998).

Quando o boro se encontra em níveis de deficiência, a divisão celular não chega a completar-se e as paredes longitudinais das células têm sua 
formação comprometida, resultando em uma expansão irregular e incompleta dos tecidos foliares (Dell et al., 1997).

A degeneração dos tecidos meristemáticos, devido a limitação na divisão celular, é facilmente notada nos pontos de crescimento, como gemas apicais, raízes, felogênio e câmbio vascular, sendo necessário um suprimento contínuo de boro para a manutenção da atividade meristemática (Hewitt \& Smith, 1975; Cohen \& Lepper, 1977; Gupta, 1979; Malavolta, 1980).

A madeira de árvores, crescendo em solos com baixos níveis de boro, pode apresentar pouca lignificação fazendo com que os ramos não suportem o peso das folhas (Dell \& Malajczuk, 1994). Lewis (1980) sugere que o boro, junto com a auxina, tem um papel primário na síntese da lignina e na diferenciação do xilema. Entretanto, são raras as pesquisas sobre os papéis do boro na diferenciação e maturação dos tecidos vasculares; e os resultados encontrados na literatura são bastante conflitantes. Essa escassez de informações dificulta a conclusão do papel do boro no processo de diferenciação dos tecidos vasculares, sendo necessário estudos adicionais dos eventos que ocorrem no processo de formação do xilema e do floema (Dell \& Huang, 1997).

Outro papel atribuído ao boro é a formação da parede celular (Hewitt \& Smith, 1975; Malavolta, 1980), sendo que o ácido bórico pode servir como unidade de ligação entre polissacarídeos na parede celular. Na sua falta, ocorrem modificações morfológicas nas plantas, tais como parede celular muito fina e pouco lignificada (Hewitt \& Smith, 1975; Lewis, 1980; Drugger, 1983; Marschner, 1986; Malavolta et al., 1989), diminuindo assim a rigidez dos tecidos.

Trevizan (2000) observou, através de cortes histológicos, que calos de E. urophylla cultivados in vitro na ausência de boro apresentavam um colapso celular, o que pode confirmar a desestruturação da parede celular reafirmando o papel estrutural do boro. Estes dados são confirmados pelas observações de Dell \& Huang (1997), os quais afirmam que a deficiência de boro parece prejudicar a expansão (inclusive mudanças no comprimento e na largura) 
celular. O desenvolvimento estrutural anormal da parede celular causado pela deficiência de boro pode ser relatado como uma diminuição drástica da plasticidade da parede celular, conduzindo a um colapso na expansão das células recém divididas.

\subsection{Sintomas de deficiência de boro}

A grande maioria dos estudos sobre nutrição de eucaliptos referem-se à fertilização com macronutrientes, sendo os efeitos dos micronutrientes no crescimento, absorção de outros nutrientes e sintomas de deficiências, relegados à segundo plano. Isso se deve principalmente pelas pequenas quantidades de micronutrientes exigidas pela planta, embora a diferença entre eles e os macronutrientes esteja apenas nas menores quantidades absorvidas e não na importância nutricional (Barros et al., 1990; Fonseca et al. 1990). A prova disso é que a deficiência de boro tem sido encontrada em plantações de eucalipto desde a década de 1950. Vail et al. (1957) e Savory (1962) relataram que o principal sintoma é a seca de ponteiro ("dieback"), sendo que as manifestações ocorrem, principalmente, durante as estações secas.

Os sintomas de deficiência de boro em eucalipto caracterizam-se por folhas novas cloróticas, pequenas e mal formadas, encarquilhadas e coriáceas; morte da gema apical e seca de ponteiro seguida de bifurcação a partir das gemas axilares; caules retorcidos; fendilhamento da casca e tronco, com exsudação de goma e necrose dos tecidos; morte descendente dos ramos e achatamento do caule devido à morte do câmbio (Tokeshi et al., 1976; Rocha Filho et al. 1978; Dell \& Malajaczuk, 1994; Silveira et al., 1995).

O fato dos sintomas da deficiência surgirem primeiramente nos órgãos mais novos e nas regiões de crescimento, indicam que em relação a redistribuição na planta, o boro possui mobilidade restrita (Malavolta, 1980; Coutinho et al. 1995; Brown \& Shelp, 1997; Malavolta et al. 1997a). Entretanto, para espécies como o Prunus $s p$, Malus $s p$. e Pyrus $s p$, as quais produzem 
quantidades significativas de sorbitol, o boro é prontamente translocado no floema, mediante a formação de complexos B-sorbitol (Brown \& Hu,1996).

Segundo Stone (1990), a deficiência de boro foi constatada em diversos paises, notadamente em espécies exóticas como Pinus e eucalipto, plantados em solos sob influência de queima ou erosão, ou em solos que sofreram aplicação de fertilizante contendo somente $N, P$ ou a combinação NP. A deficiência severa causou diminuição no crescimento, baixa sobrevivência e em casos mais severos caules deformados e menor qualidade da madeira produzida.

Vale et al. (1995) relataram que os sintomas da deficiência de boro em E. globulus numa região de Trás-os-Montes, em Portugal, caracterizaram-se por folhas novas cloróticas, com as margens irregulares e nervuras salientes. Algumas folhas apresentaram manchas avermelhadas no limbo. Morte dos brotos seguida de superbrotação das gemas axilares, sendo comum plantas com caules tortuosos ou bifurcados. A ausência de dominância apical conferiu às plantas um aspecto arbustivo. Nas plantas deficientes foi freqüente a presença de árvores e ramos quebrados, principalmente após períodos de chuva e ventos fortes.

Segundo Real (2000), a deficiência de boro em solos do Uruguai é uma das principais causas da diminuição da produtividade florestal. As deficiências ocorrem principalmente em solos arenosos e com baixa capacidade de retenção de água. Entretanto, diversas práticas silviculturas podem acentuar o problema, tanto pelo esgotamento do nutriente, ou como conseqüência do uso de adubação NPK sem micronutrientes em sua composição. Os principais sintomas de deficiência encontrados pelo autor foram a seca de ponteiro e rachaduras no tronco, além de árvores mais susceptiveis ao cancro ocasionada por Botryosphaeria dothidea. Resultados semelhantes aos encontrados por Real (2000) foram verificados por Silveira et al. (1998) em E. citriodora, onde a deficiência de boro aumentou a agressividade do fungo Botryosphaeria ribis. 
Carvalho et al. (1980), observaram sintomas de deficiência de boro em plantações de Eucalyptus saligna. Em plantas jovens, ocorreu a morte generalizada dos ponteiros, ramificações excessivas e menor porte das plantas.

Segundo Dell \& Malajaczuk (1994), a deficiência de boro foi relatada como a principal causa de caules tortuosos e folhas deformadas em plantações de E. globulus, E. grandis, E. tereticornis e E. urophylla na China. Os sintomas de deficiência em $E$. globulus foram folhas encarquilhadas e mal formadas, caules retorcidos e morte descendente de ramos. Em E. urophylla, folhas com clorose, seguida de necrose das margens, coriáceas, morte de brotos seguida de superbrotação das gemas axilares. Em E. grandis, a morte descendente de ramos foi precedida pelo acúmulo de antocianina nas folhas novas. Plantas de E. tereticornis deficientes em boro, apresentaram folhas com clorose marginal, internerval e margens recurvadas. A concentração de boro nas folhas novas de E. globulus sadio foi de $36 \mathrm{mg} \mathrm{kg}^{-1}$ no material seco quando comparado com 10 $\mathrm{mg} \mathrm{kg}^{-1}$ nas árvores de caules retorcidos. Sintomas não foram constatados em plantações de $E$. globulus que receberam fertilizantes boratados.

Silveira et al. (1996) estudando os sintomas de deficiência de macronutrientes e B em clone híbrido de $E$. grandis $\times E$. urophylla cultivado em solução nutritiva, descreveram que os sintomas de deficiência de boro foram: folhas novas com intensa clorose marginal seguida de secamento das margens, as nervuras dessas folhas apresentavam-se externamente salientes com posterior necrose, dando um aspecto de "costelamento". Relataram ainda que as folhas apresentavam-se encarquilhadas e espessas; com perda de dominância causada pela morte da gema apical, sendo que no estágio mais avançado ocorreu severa seca de ponteiro e morte descendentes de ramos, precedido do superbrotamento das gemas laterais ao longo do caule. Os autores também relataram que a deficiência de boro e a de nitrogênio foram as que mais reduziram o crescimento das plantas. Na omissão de boro, observaram concentrações de $15 \mathrm{mg} \mathrm{B} \mathrm{kg}^{-1}$ nas folhas novas, $22 \mathrm{mg} \mathrm{B} \mathrm{kg}^{-1}$ na

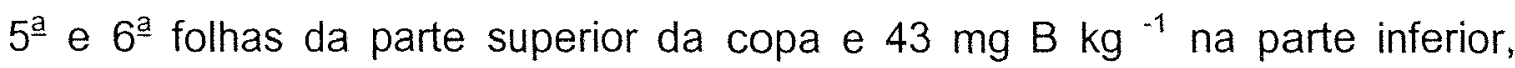


enquanto que na presença de boro verificaram $39 \mathrm{mg} \mathrm{B} \mathrm{kg}^{-1}$ nas folhas novas, $38 \mathrm{mg} \mathrm{B} \mathrm{kg}^{-1}$ na $5^{\mathrm{a}}$ e $6^{\mathrm{a}}$ folhas da parte superior da copa e $41 \mathrm{mg} \mathrm{B} \mathrm{kg}^{-1} \mathrm{na}$ parte inferior.

Igualmente ao que ocorre na parte aérea do eucalipto, os sintomas de deficiência de boro manifestam-se também nas raízes. Rocha Filho et al. (1978) observaram que na ausência de boro ocorreu o atrofiamento do sistema radicular. Coutinho et al. (1995) citam que a conseqüência mais imediata deste atrofiamento é a diminuição do volume de solo explorado pelas raízes que se traduz numa menor absorção de água e nutrientes. A sintomatologia descrita por Malavolta et al. (1997b) caracteriza-se por raízes escuras com pontas grossas e posteriormente necróticas e ramificadas. Para Dell \& Huang (1997), os efeitos da deficiência de boro no crescimento das raízes é de extremo interesse, uma vez que, o desenvolvimento anormal das raizes diminuiria a habilidade das plantas na absorção e no transporte de outros nutrientes, podendo induzir outras deficiências nutricionas.

\subsection{Faixas adequadas e deficientes dos nutrientes}

A classificação da concentração dos elementos em níveis deficientes e adequados serve para interpretação das análises do tecido foliar. Segundo Malavolta et al. (1997b), os teores de macronutrientes $\left(\mathrm{g} \mathrm{kg}^{-1}\right)$ e micronutrientes ( $\mathrm{mg} \mathrm{kg}^{-1}$ ) associados a altas produtividades de Eucalyptus grandis são: $\mathrm{N}=21$ a 23; $\mathrm{P}=1,3$ a 1,$4 ; \mathrm{K}=9$ a $10 ; \mathrm{Ca}=5$ a $6 ; \mathrm{Mg}=2,5$ a $3 ; \mathrm{S}=1,5$ a 2,$5 ; \mathrm{B}=25$ a 30; $\mathrm{Cu}=7$ a $10 ; \mathrm{Fe}=100$ a $140 ; \mathrm{Mn}=300$ a 400 e $\mathrm{Zn}=12$ a 17 . As faixas consideradas adequadas e deficientes para os macro e micronutrientes nas folhas de Eucalyptus de acordo com diversos autores encontram-se na Tabela 1. 
Tabela 1. Teores dos nutrientes considerados adequados e deficientes na matéria seca de folhas de eucalipto, segundo diversos autores.

\begin{tabular}{|c|c|c|c|c|c|c|}
\hline \multirow[b]{2}{*}{ Elemento } & \multicolumn{3}{|c|}{ Faixa adequada } & \multicolumn{3}{|c|}{ Faixa deficiente } \\
\hline & $\begin{array}{c}\text { Dell } \\
\text { et al. } \\
(1995)^{1}\end{array}$ & $\begin{array}{c}\text { Gonçalves } \\
\text { et al. } \\
(1995)^{2}\end{array}$ & $\begin{array}{c}\text { Silveira } \\
\text { et al. } \\
(1999)^{1}\end{array}$ & $\begin{array}{c}\text { Boardamn } \\
\text { et al. } \\
(1997)^{3}\end{array}$ & $\begin{array}{c}\text { Malavolta } \\
\text { et al. } \\
(1987)^{2}\end{array}$ & $\begin{array}{c}\text { Silveira } \\
\text { et al. } \\
(1999)^{1}\end{array}$ \\
\hline$N$ & $18-34$ & $13,5-18$ & $\begin{array}{c}g^{g k g^{-1}} \\
22-27\end{array}$ & $<15$ & $8-13$ & $<16$ \\
\hline $\mathrm{P}$ & $1-2,2$ & $0,9-1,3$ & $1,7-2.2$ & $<0,7$ & $0,4-0,8$ & $<1,1$ \\
\hline $\mathrm{K}$ & $9-18$ & $9-13$ & $8,5-9$ & $<5$ & $6-8$ & $<7$ \\
\hline $\mathrm{Ca}$ & $3-6$ & $6-10$ & $7,1-11$ & $<1$ & $2-4$ & $<5,5$ \\
\hline $\mathrm{Mg}$ & $1,1-2,1$ & $3,5-5$ & $2,5-2,8$ & $<0,6$ & $1,5-2$ & $<2,1$ \\
\hline$S$ & $1,5-2,3$ & $1,5-2$ & $\begin{array}{l}1,5-2,1 \\
\mathrm{mg} \mathrm{kg}^{-1}\end{array}$ & $<1$ & $0,8-1,2$ & $<1,3$ \\
\hline$B$ & $15-27$ & $30-50$ & $34-44$ & $<8$ & $15-20$ & $<21$ \\
\hline $\mathrm{Cu}$ & $2-7,4$ & $7-10$ & $6-7$ & $<2$ & $4-6$ & $<4$ \\
\hline $\mathrm{Fe}$ & $63-128$ & $150-200$ & $65-125$ & $=$ & $75-100$ & \\
\hline $\mathrm{Mn}$ & $193-547$ & $400-600$ & $200-840$ & - & $<100$ & \\
\hline $\mathrm{Zn}$ & $17-42$ & $35-50$ & $15-20$ & $<7$ & $20-30$ & $<7$ \\
\hline
\end{tabular}

\subsection{Resposta do eucalipto à aplicação de boro}

Segundo Balloni (1977), a necessidade do uso de adubos contendo boro em essências florestais, partiu de observações feitas por Savory (1962), na Namíbia, onde havia intensa seca de ponteiro em diferentes espécies de Pinus e eucalipto. Inicialmente pensava-se que o problema era efeito direto da falta de água, entretanto após estudos experimentais concluiu-se que a ocorrência de seca de ponteiro era devido a falta de boro.

Cooling \& Jones (1970), ao estudarem aplicação de tetraborato de sódio e fertilizante NPK em Eucalyptus grandis, na Zâmbia, verificaram que nas parcelas que receberam boro houve um maior desenvolvimento das plantas, redução da morte dos ponteiros e uma indução do florescimento. Os autores concluíram que $8 \mathrm{~g} \mathrm{~B}$ por planta na forma de tetraborato de sódio foram suficientes para suprir as exigências nutricionais do Eucalyptus grandis em relação ao boro. Resultados semelhantes foram encontrados por Tokeshi et al. 
(1976) ao estudarem a influência da aplicação de boro em povoamento de Eucalyptus citriodora aos 12 meses de idade, com sintomas generalizados de deficiência de boro. As doses utilizadas foram: 0, 6,0, 12,0 e 18,0 g B por planta. Os resultados mostraram um efeito benéfico da aplicação, reduzindo o número de plantas com sintomas de deficiência de $67,5 \%$, na dose $0 \mathrm{~g}$ de $\mathrm{B}$ planta, a $2,45 \%$ e 2,85\% nas doses de 12 e $18 \mathrm{~g}$ de B por planta, respectivamente.

Novelino et al. (1982) estudando a exigência de boro em relação a quatro espécies de eucalipto ( $E$. camaldulensis, $E$. citriodora, $E$. grandis e $E$. paniculata) em condições de solução nutritiva com diferentes níveis de boro ( 0 ; 0,$02 ; 0,1 ; 0,5$ e $2,5 \mathrm{mg} \mathrm{B} \mathrm{L}^{-1}$ ), observaram respostas diferenciadas quanto as espécies. A produção máxima de matéria seca de $E$. camaldulensis ocorreu no nível de $0,02 \mathrm{mg} \mathrm{B} \mathrm{L}^{-1}$, já para o $E$. grandis e E. citriodora quando estes foram cultivados em $0,1 \mathrm{mg} \mathrm{B} \mathrm{L}^{-1}$ e para o E. paniculata em torno de $0,5 \mathrm{mg} \mathrm{B} \mathrm{L}^{-1}$. O E. grandis foi a espécie que apresentou a faixa mais estreita entre a produção máxima e a fitotoxicidade, ocorrendo perdas de produção para níveis acima de

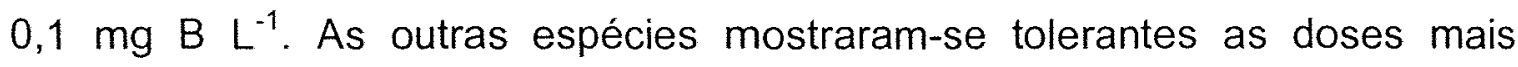
elevadas desse micronutriente, havendo pequena redução de crescimento entre a dose ótima e o nível mais elevado, $2,5 \mathrm{mg} \mathrm{B} \mathrm{L}^{-1}$.

Coutinho et al. (1995) instalaram vários experimentos em diferentes regiões de Portugal, para avaliar o efeito de doses de boro sobre o crescimento de $E$. globulus. As doses utilizadas foram de 2,2; 4,4 e 8,8 $\mathrm{kg}$ de $\mathrm{B} \mathrm{ha}{ }^{-1}$. Esses autores observaram que, nas regiões de Vila Real e Castelo Banco, a aplicação de boro proporcionou um aumento na altura média das árvores de 26,6 \% e $93,2 \%$, respectivamente, aos 12 meses de idade. Observaram também que, a aplicação de 4,4 e $8,8 \mathrm{~kg}$ de $\mathrm{B} \mathrm{ha}{ }^{-1}$, causou sintomas de fitotoxicidade nas plantas de E. globulus.

Silveira et al. (1998) num ensaio para avaliar o efeito de doses de boro $\left(0 ; 0,125 ; 0,25 ; 0,5 ; 1,0 ; 2,0\right.$ e $\left.4,0 \mathrm{mg} \mathrm{L}^{-1}\right)$ sobre a concentração de nutrientes em Eucalyptus citriodora, observaram que aos 150 dias após o início dos 
tratamentos, as plantas cultivadas na ausência de boro mostravam os primeiros sintomas da deficiência, caracterizado por folhas novas de tamanho reduzido, deformadas, encarquilhadas e coriáceas, com uma leve clorose, geralmente marginal. Num estágio mais avançado, ocorreu a morte das gemas apicais, seguida de morte descendente do ponteiro da planta, associada à emissão de brotação das gemas laterais ao longo do tronco ou na base do lignotuber, resultando na paralisação do crescimento em altura. Observaram também um efeito significativo das doses de boro sobre a concentração nas diferentes partes da planta. $\mathrm{Na}$ ausência de boro, as concentrações obtidas nas folhas superiores e inferiores foram de $7,2 \mathrm{mg} \mathrm{B}^{-1}$ e 13,82 $\mathrm{mg} \mathrm{B} \mathrm{kg}^{-1}$, respectivamente. Em relação à dose mais elevada de boro, as concentrações obtidas foram de $201,2 \mathrm{mg} \mathrm{B} \mathrm{kg}^{-1}$ e $240,3 \mathrm{mg} \mathrm{B} \mathrm{kg}^{-1}$ para folhas superiores e inferiores.

Stape (1992) estudando a fertilização do Eucalyptus grandis em areia quartzosa de baixa fertilidade ( $94 \%$ areia), numa região de déficit hídrico intenso, observou ganhos de volume de madeira de 118 e $81 \%$ e ausência de seca de ponteiro quando aplicou NPK mais micronutrientes na forma de óxidos silicatados, em comparação com a testemunha e com a adubação tradicional do eucalipto (sem micronutrientes). Segundo o autor, tais ganhos se devem provavelmente à correção da deficiência de micronutrientes, praticamente inexistentes nestes solos, esse fato se evidencia também pela não ocorrência de seca de ponteiro, o que deve ser reflexo de uma boa nutrição em termos de micronutrientes, notadamente boro e zinco.

Sgarbi \& Silveira (1999) estudando a resposta do eucalipto à aplicação de boro na região de Três-Marias (MG), a qual apresenta períodos de déficit hídrico durante o ano, constataram uma redução de $35 \%$ na seca de ponteiro com a aplicação de $2,2 \mathrm{~kg} \mathrm{~B} \mathrm{ha}^{-1}$ em solo arenoso, e de $45 \%$ em solo argiloso. Além de ganhos de até $17 \%$ em altura para ambos os solos.

Moraes (1999) estudando o efeito das doses de boro $(0 ; 1,1 ; 2,2$ e 4,4 $\mathrm{g} /$ planta) sobre o crescimento e a intensidade de seca de ponteiro em diferentes 
espécies de Eucalyptus, obteve respostas diferenciadas entre as espécies em relação à aplicação de boro. $\mathrm{Na}$ ausência do nutriente, o $E$. citriodora e o $E$. camaldulensis procedência Port Headland foram mais susceptiveis a seca de ponteiro. A aplicação de $2,2 \mathrm{~g}$ de $\mathrm{B}$ por planta foi suficiente para que os sintomas de seca de ponteiro no $E$. camaldulensis desaparecessem, entretanto para o E. citriodora a dose necessária foi de $4,4 \mathrm{~g}$ por planta. Com exceção do E. camaldulensis procedência Sussuarana e E. pellita procedência Patagônia, os ganhos em altura foram de 15 a $33 \%$.

Fonseca et al. (1990) avaliaram o efeito da aplicação de boro e zinco no desenvolvimento do Eucalyptus camaldulensis em um latossolo vermelhoamarelo textura média, na região de Brasilândia - MG. Foram testadas três doses de bórax e sulfato de zinco. Aos 30 meses de idade, foram obtidos ganhos de 25 a $32 \%$ em volume $\left(\mathrm{m}^{3}\right.$ ha $\left.^{-1}\right)$ em relação à testemunha, com a aplicação de 2,4 e 4,8 $\mathrm{kg}$ de $\mathrm{B} \mathrm{ha}^{-1}$, respectivamente. O sulfato de zinco afetou negativamente o crescimento do eucalipto, sendo que na presença de boro esse efeito depressivo foi reduzido em menor ou maior proporção em função da combinação das doses.

Giovanetti (1999) encontrou resposta positiva em DAP com a aplicação de boro em eucalipto, em latossolo textura arenosa, na região de Lençóis Paulista. A adição de $2,8 \mathrm{~kg} \mathrm{~B} \mathrm{ha}^{-1}$ proporcionou um aumento de $9 \%$ no DAP em relação à testemunha, aos 2,5 anos de idade.

Benedetti (1999) estudando o efeito da aplicação de boro em plantações de eucalipto, na região de Anhembi - SP, observou que a dose de 4 $\mathrm{kg} \mathrm{B} \mathrm{ha-1}$ foi a que proporcionou maior crescimento em volume, aos 5 meses de idade. Entretanto, o aumento do fornecimento de boro, 6 e $8 \mathrm{~kg} \mathrm{~B} \mathrm{ha-1,}$ promoveu perdas de produtividade da ordem de 7 e $20 \%$, respectivamente. Segundo o autor, altas doses de boro aplicadas na época chuvosa, podem causar fitotoxicidade ao eucalipto. 


\subsection{Efeitos da adubação e do estado nutricional sobre as características físicas e anatômicas da madeira}

No Brasil, a adubação passou a ser considerada uma prática interessante, a partir do momento em que os plantios florestais começaram a ser feitos em regiões de solo com baixa fertilidade. Embora a adubação resulte em ganhos de produtividade, pouca atenção tem sido dispensada aos possiveis efeitos que ela possa ter sobre a qualidade da matéria-prima florestal produzida. Ainda se sabe muito pouco a respeito dos niveis das influências desta prática nas qualidades físicas, químicas e anatômicas da madeira, sobretudo quando se trata de florestas de folhosas (Andrade et al., 1994).

O conceito de qualidade da madeira, que evoluiu ao longo dos tempos, é hoje encarado como um conceito dinâmico que integra o conjunto de características anatômicas, físicas e químicas e de resistência que conferem a aptidão à madeira para determinado uso final. A qualidade da madeira que está sendo produzida em plantações florestais pode, dentro de certos limites, ser influenciada por diferentes práticas silviculturais como o desbaste, a desrama e a fertilização (Jorge \& Pereira, 1998).

A formação da madeira e suas características dependem da atividade cambial e da diferenciação do xilema. Estes por sua vez são controlados pela produção de hormônios nas gemas foliares. Os hormônios sintetizados na copa são transportados para o câmbio através do floema, onde se inicia então a diferenciação do xilema. Uma mudança da fertilidade do solo através da adição de fertilizantes, irá influenciar diretamente a atividade da copa, aumentando a superfície das folhas e consequentemente a produção de hormônios (Siddiqui, 1972; Shimoyama \& Barrichelo, 1989).

$\mathrm{Na}$ madeira de folhosas, existe uma maior variabilidade estrutural e complexidade anatômica que integra mais tipos de células (principalmente fibras, parênquima e elementos de vasos), deste modo, além da variabilidade biométrica, também deve ser considerada as diferentes proporções de cada um 
dos tipos de células. A variabilidade na árvore é inevitável, uma vez que está associada em grande parte ao processo de formação do xilema, isto é, a madeira da árvore jovem formada nos primeiros anos de vida ou sob influência direta da copa é diferente da formada pela mesma árvore no estado adulto. $O$ lenho juvenil ocupa a parte central de qualquer tronco e apresenta características próprias que a distinguem do lenho adulto relativamente a aspectos, tais como, a estrutura da camada de crescimento, a biometria das células, a composição química, as propriedades físicas e as resistências mecânicas. No lenho juvenil, as propriedades não são uniformes, e variam muito rapidamente da medula para a periferia (Jorge \& Pereira, 1998).

A densidade básica tem sido o índice mais empregado para a avaliação da qualidade da madeira em plantações florestais, devido a grande facilidade em sua determinação, pelas excelentes relações que mostra com as utilidades da madeira e por ser uma das variáveis que apresenta maior correlação com outros parâmetros de qualidade (Ferreira \& Kageyama, 1978; Lima et al., 1992; Foelkel et al., 1992; Teixeira \& Mendes, 1995; Downes \& Raymond, 1997). A densidade da madeira apresenta ampla variação entre árvores, entre espécies e dentro da mesma árvore, no sentido base-topo e medula-casca, podendo também ser influenciada pelas características genéticas, pelo sítio (clima e solo), práticas silviculturais (adubação, espaçamento de plantio, preparo do solo, liberação da competição das plantas daninhas, etc.), taxa de crescimento, nível de produtividade e idade (Brasil, 1972; Foelkel et al., 1975; Ferreira \& Kageyama, 1978; Tomazello Filho, 1985; Vale et al., 1985; Souza et al., 1986).

Segundo Vital (1990) a densidade da madeira é essencialmente função da espessura da parede celular, das dimensões e dos tipos de células e do teor de extrativos. O efeito da adubação na densidade da madeira é, portanto, decorrente de alterações nestes parâmetros e depende, entre outras coisas, da fertilidade original do solo, da espécie florestal, da taxa de crescimento e do tipo de fertilizante utilizado. 
A maioria dos trabalhos que tratam da influência das práticas silviculturais, relatam que os tratamentos que aumentam a taxa de crescimento das árvores de eucalipto tendem a diminuir a densidade básica da madeira (Migliorini, 1986; Wilkins, 1990; Wilkins \& Horne, 1991; Wilkins \& Kitahara, 1991). Albino \& Tomazello Filho (1984) estudando a densidade básica da madeira de 12 espécies de eucalipto, verificaram que em termos médios, no local de maior crescimento, onde o solo era mais fértil, a densidade básica da madeira foi menor e no local de menor crescimento e de menor fertilidade, a densidade básica média foi maior. O mesmo foi observado por Ferreira et al. (1979) em plantios de eucalipto, na região de Mogi-Guaçu - SP.

Mello (1968) com o objetivo de estudar o efeito da adubação isolada de $\mathrm{N}, \mathrm{P}, \mathrm{K}$ e $\mathrm{Ca}$ e suas combinações na qualidade da madeira de Eucalyptus saligna, verificou que a densidade básica, a espessura e o comprimento das fibras não foram influenciadas pela adubação nitrogenada, fosfatada e potássica, entretanto, a aplicação de $2 \mathrm{t} \mathrm{ha}^{-1}$ de calcário reduziu em $3,3 \%$ o comprimento das fibras em relação à testemunha. Estes resultados, entretanto, são discordantes dos obtidos por Higgs \& Rudman (1973), que observaram uma redução na densidade básica da madeira em um povoamento de Eucalyptus regnans, com idades variando de 27 a 34 anos, após aplicação conjunta de NPK.

Balloni (1984) estudou o efeito das doses de $\mathrm{N}, \mathrm{P}, \mathrm{K}$ e $\mathrm{Ca}$ e das combinações NP, NK, NCa, PK, PCa e KCa sobre a densidade básica da madeira de Pinus caribaea var. bahamensis, aos 11,5 anos de idade. $O$ autor observou que a adição de potássio promoveu ganhos de $9 \%$ em volume, porém, teve a densidade básica diminuída em aproximadamente 4,5\%. A adubação fosfatada apesar de promover um ganho de $12 \%$ em volume, praticamente não afetou a densidade básica da madeira. $O$ autor concluiu que possivelmente, em relação ao potássio, exista uma ação direta sobre a densidade da madeira independente da taxa de crescimento, uma vez que a resposta ao $\mathrm{P}$ foi até superior à de $\mathrm{K}$, sem entretanto, afetar a densidade. Já a 
adição de Ca reduziu a densidade da madeira em $11 \%$, isso provavelmente se deve ao maior ritmo de crescimento proporcionado pela adição desse nutriente, o qual elevou o volume em $34 \%$ em relação as parcelas não adubadas.

Subrahmanyam (1988) estudando o efeito da aplicação de fertilizante nitrogenado e fosfatado sobre o comprimento das fibras de E. grandis, na Índia, em solos deficientes desses nutrientes, verificou que elevadas doses de $\mathrm{N}$ contribuíram para o aumento do comprimento médio das fibras, o oposto foi observado para níveis elevados de fósforo. No entanto, a parede celular foi mais espessa nas plantas cultivadas em altas doses de fósforo e baixas de nitrogênio.

Brito (1985) verificou que a adubação de Pinus caribaea var. bahamensis com $60 \mathrm{~kg}$ de $\mathrm{N} \mathrm{ha}^{-1}, 100 \mathrm{~kg}$ de $\mathrm{P}_{2} \mathrm{O}_{5}$ ha $^{-1}$ e $40 \mathrm{~kg}_{\text {de } \mathrm{K}_{2}} \mathrm{O}$ ha ${ }^{-1}$ e $3 \mathrm{t}$ de calcário dolomítico ha ${ }^{-1}$ reduziu a densidade básica em cerca de $27 \%$, quando comparada aquela obtida de árvores não adubadas.

Andrade et al. (1994) avaliaram os efeitos das adubações fosfatada, sulfatada e da calagem do solo sobre a produção e a qualidade da madeira de Eucalyptus grandis, aos seis anos de idade. Os autores não observaram diferenças significativas na densidade básica do cerne e do alburno das árvores adubadas. O lenho das árvores fertilizadas com fosfato e gesso apresentou, em relação às testemunhas, fibras com menores diâmetros e espessura de parede celular.

Sgarbi et al. (2000) relataram que a omissão de enxofre reduziu em $11 \%$ a densidade básica da região basal do caule de $E$. grandis $\times E$. urophylla cultivados em solução nutritiva. Em relação ao comprimento das fibras da madeira, verificaram que a omissão de Ca proporcionou uma redução de 15\% no comprimento em relação ao tratamento completo. As plantas cultivadas na ausência múltipla de $\mathrm{K}, \mathrm{B}$ e $\mathrm{Zn}$, quando comparadas às do tratamento completo, tiveram diminuição de $25 \%$ na largura e de $42 \%$ na espessura da parede das fibras da madeira; e em relação ao diâmetro do lume das fibras, não observaram efeito significativo das deficiências nutricionais. 
Silveira (2000) estudando o efeito do potássio nas características da madeira de quatro progênies de $E$. grandis em solução nutritiva, verificou que somente a progênie 1 não teve o comprimento e a largura das fibras influenciadas pela adição de potássio. Nos demais materiais genéticos, o potássio afetou positivamente tanto o comprimento como a largura das fibras. Independente do genótipo analisado o comprimento das fibras foi maior nas plantas cultivadas com doses de 175,5 e $526,5 \mathrm{mg} \mathrm{K} \mathrm{L}^{-1}$.

\section{6 fenômeno da geada}

A ocorrência de geadas é pouco freqüente na região sudeste, porém, apesar de ser um evento esporádico, proporcionam enormes prejuízos à atividade florestal, prejudicando o desenvolvimento de florestas adultas e propiciando a morte de espécies menos tolerantes (ex. E. dunnii e E. viminaliis) ou plantas mais jovens (Garcia \& Santos, 1995; Higa et al., 1995).

Os danos nos vegetais são decorrentes do congelamento dos líquidos presentes nos espaços intercelulares, havendo ruptura de membranas por compressão e extravasamento irreversivel do citoplasma (Garcia \& Santos, 1995; Higa et al., 1995).

Segundo os levantamentos realizados pelo Instituto de Pesquisas e Estudos Florestais (IPEF) e pela Empresa Brasileira de Pesquisa Agropecuária (EMBRAPA), em 1994 a ocorrência de geadas foi intensa, sendo registradas temperaturas que oscilaram entre $-2^{\circ} \mathrm{C}$ e $-7^{\circ} \mathrm{C}$. Os povoamentos mais jovens foram os mais afetados, não deixando entretanto de prejudicar florestas adultas, especialmente aquelas localizadas em posições mais baixas do relevo. Foram detectadas desde a queima dos ponteiros até a perda total da copa, em inúmeros casos. No Estado de São Paulo, a geada atingiu, naquele ano, 30.000 ha de floresta implantada, estimando-se uma perda de $50 \%$ desse total. $\mathrm{Na}$ região de Botucatu e Itatinga, a área total atingida foi de 3.900 ha de floresta implantada com espécies de Eucalyptus grandis, Eucalyptus saligna e 
Eucalyptus urophylla, com idades variando de 5 meses a 3 anos (Garcia \& Santos, 1995).

Vários são os métodos utilizados para avaliação dos danos ou resistência à geada em mudas de eucalipto. Lisbão Júnior (1980), após a ocorrência de uma geada, quando foi registrada temperatura de $-2,5^{\circ} \mathrm{C}$, avaliou os danos causados as mudas de Eucalyptus dunnii utilizando uma classificação previamente estabelecida, a qual estava dividida em três niveis: nível $1=$ queima total das folhas; nivel 2 = queima parcial das folhas e nível $3=$ sem danos. Já Higa (1993), utilizou o método da condutividade elétrica para avaliar a resistência à geada de mudas de Eucalyptus viminalis submetidas a temperaturas que variaram de $0^{\circ} \mathrm{C}$ a $4^{\circ} \mathrm{C}$, durante 48 horas, numa câmara fria. O método consistiu basicamente nas medições da condutividade das amostras de folhas submetidas a temperaturas abaixo do ponto de congelamento. Segundo o autor, esse método é mais indicado para experimentos realizados em laboratório.

Lisbão Júnior (1986) comparou dois métodos de avaliação e análise da resistência à geada em mudas de eucaliptos. Um dos métodos consistiu na classificação das mudas em seis classes, variando de $0=$ muito afetada até $5=$ não afetada pela geada. Outro método avaliou a resistência à geada pelo conteúdo de umidade das mudas. Os resultados mostraram que os dois métodos de avaliação e análise da resistência à geada, apresentaram uma equivalência de interpretações. Porém, a avaliação por nota apresentou, quando comparado ao método de avaliação do conteúdo de umidade, as seguintes vantagens: ser um método não destrutivo, permitindo a avaliação no campo ou em laboratório; não requer a utilização de equipamentos e maior simplicidade de análise.

Sutinen et al. (1992) utilizaram dois métodos para avaliar o efeito sazonal da geada em Pinus resinosa e Pinus nigra. Um dos métodos consistiu na observação visual e o outro na medição do extravasamento celular de eletrólitos. Durante mais de um ano, a resistência à geada foi determinada 
pelos dois métodos, ambos apresentaram resultados similares. Porém, o método que mediu o extravasamento celular de eletrólitos forneceu uma boa estimativa das mudanças sazonais na resistência à geada, exceto para o Pinus resinosa em condições de inverno rigoroso. Nesse caso, para a obtenção de dados confiáveis os autores sugeriram a combinação do método do extravasamento celular de eletrólitos com a observação visual. Esses dois métodos também foram utilizados por Jalkanen et al.(1998) para avaliar a resistência à geada em Picea sitchensis. 


\section{MATERIAL E MÉTODOS}

\subsection{Escolha da área}

O experimento foi instalado na Cia. Suzano de Papel e Celulose, na região de Itatinga-SP, em outubro de 1999. Essa região possui grande atuação no setor florestal, em torno de 50.000 ha de plantações de eucalipto produzindo madeira para diversos fins, como para obtenção de pasta celulósica, fabricação de chapas, aglomerados e painéis. A escolha da área foi motivada devido ao tipo de solo, areia quartzosa, de baixa fertilidade natural, onde o boro normalmente ocorre em niveis limitantes.

O experimento ocupou uma área total de 2,5 ha.

\subsection{Material genético}

Foram utilizados dois clones de Eucalyptus grandis considerados de alta produtividade pela empresa, clone $A 1$ e clone $A 2$, sendo o clone $A 1$ mais susceptível à deficiência de boro. As mudas foram fornecidas pela empresa, e quando atingiram a idade de 90 dias foram selecionadas no viveiro florestal e plantadas no campo.

\subsection{Delineamento experimental}

O experimento foi realizado em blocos ao acaso, sendo os tratamentos distribuídos num arranjo fatorial $6 \times 2$ (6 doses $\times 2$ clones) e 4 repetições (blocos), totalizando 48 parcelas experimentais (Figura 1). Cada parcela foi 
constituída por 8 linhas de 11 plantas em espaçamento $3 \times 2 \mathrm{~m}$, sendo consideradas para avaliação somente as 28 plantas úteis centrais.

$\begin{array}{llllllll}0 & 0 & 0 & 0 & 0 & 0 & 0 & 0 \\ 0 & 0 & 0 & 0 & 0 & 0 & 0 & 0 \\ 0 & 0 & x & x & x & x & 0 & 0 \\ 0 & 0 & x & x & x & x & 0 & 0 \\ 0 & 0 & x & x & x & x & 0 & 0 \\ 0 & 0 & x & x & x & x & 0 & 0 \\ 0 & 0 & x & x & x & x & 0 & 0 \\ 0 & 0 & x & x & x & x & 0 & 0 \\ 0 & 0 & x & x & x & x & 0 & 0 \\ 0 & 0 & 0 & 0 & 0 & 0 & 0 & 0 \\ 0 & 0 & 0 & 0 & 0 & 0 & 0 & 0\end{array}$

Figura 1- Esquema da parcela experimental $(X=$ plantas úteis $O=$ bordadura da parcela).

\subsection{Análise estatística}

Foram feitas análises de variância ( Tabela 2), teste de comparação de médias (Teste de Tukey, ao nivel de $5 \%$ de significância), e regressões entre:

$\checkmark$ Doses de boro $x$ altura;

$\checkmark$ Doses de boro $\times$ DAP;

$\checkmark$ Doses de boro $x$ volume;

$\checkmark$ Doses de boro $x$ concentração de macro e micronutrientes nas folhas;

$\checkmark$ Doses de boro x comprimento, largura, espessura, fração parede e diâmetro do lume das fibras;

$\checkmark$ Doses de boro $x$ densidade básica da madeira;

$\checkmark$ Concentração de boro nas folhas diagnóstico $x$ volume. 
Tabela 2. Esquema da análise de variância

\begin{tabular}{ccc}
\hline Causas de variação & \multicolumn{2}{c}{ Grau de Liberdade } \\
\hline Clones $(\mathrm{a})$ & $(\mathrm{i}-1)$ & 1 \\
Doses de B $(\mathrm{b})$ & $(\mathrm{k}-1)$ & 5 \\
$\mathrm{a} \times \mathrm{b}$ & $(\mathrm{i}-1) \times(\mathrm{k}-1)$ & 5 \\
(Tratamentos) & $(\Sigma)$ & $(11)$ \\
Resíduo & {$\left[\mathrm{j}^{\mathrm{A}} \times(\mathrm{ik})-1\right]-\Sigma$} & 36 \\
Total & $\mathrm{j} \times(\mathrm{ik})-1$ & 47 \\
\hline
\end{tabular}

A-repetições.

Para avaliação dos dados, utilizaram-se as análises de variância e de regressão através do programa estatístico Statistical Analysis Sistem (SAS, Institute, 1990).

\subsection{Amostragem de solo}

Dois meses antes da instalação do experimento, foram feitas amostragens de solo em duas profundidades $(0-15 \mathrm{~cm}$ e $15-30 \mathrm{~cm})$ para avaliação das características químicas (Tabela 3). A área foi dividida em duas glebas, uma formada pelos blocos BI e Bll e outra pelos blocos BIII e BIV. De cada gleba foi coletada ao acaso 20 amostras simples nas duas profundidades. As amostras simples foram reunidas formando uma amostra composta representativa da área, totalizando 4 amostras de solo $(2$ glebas $\times 2$ profundidades).

A análise química do solo foi feita no Departamento de Solos e Nutrição de Plantas da ESALQ/USP. 
Tabela 3. Características químicas do solo em duas profundidades, antes da instalação do experimento.

\begin{tabular}{|c|c|c|c|c|}
\hline & \multicolumn{2}{|c|}{ Amostra I } & \multicolumn{2}{|c|}{ Amostra II } \\
\hline & $0-15 \mathrm{~cm}$ & $15-30 \mathrm{~cm}$ & $0.15 \mathrm{~cm}$ & $15-30 \mathrm{~cm}$ \\
\hline $\mathrm{pH} \mathrm{CaCl}_{2}$ & 3,4 & 3,5 & 3,5 & 3,6 \\
\hline M.O. $\left(\mathrm{g} \mathrm{dm}^{-3}\right)$ & 26 & 16 & 19 & 19 \\
\hline$P\left(\mathrm{mg} \mathrm{dm}^{-3}\right)$ & 3 & 16 & 4 & 3 \\
\hline $\mathrm{S}-\mathrm{SO}_{4}\left(\mathrm{mg} \mathrm{dm}^{-3}\right)$ & 4 & 2 & 4 & 3 \\
\hline $\mathrm{K}\left(\mathrm{mmolc} \mathrm{dm}^{-3}\right)$ & 0,4 & 0,4 & 0,4 & 0,3 \\
\hline $\mathrm{Ca}\left(\mathrm{mmolc} \mathrm{dm}^{-3}\right)$ & 1 & 3 & 1 & 1 \\
\hline $\mathrm{Mg}\left(\mathrm{mmolc} \mathrm{dm}^{-3}\right)$ & 1 & 1 & 1 & 1 \\
\hline $\mathrm{Al}\left(\mathrm{mmolc} \mathrm{dm}^{-3}\right)$ & 12 & 10 & 10 & 9 \\
\hline $\mathrm{H}+\mathrm{Al}\left(\mathrm{mmolc} \mathrm{dm}^{-3}\right)$ & 72 & 52 & 58 & 42 \\
\hline $\mathrm{SB}\left(\mathrm{mmolc} \mathrm{dm}^{-3}\right)$ & 2,4 & 4,4 & 2,4 & 2,3 \\
\hline $\mathrm{T}\left(\mathrm{mmolc} \mathrm{dm}^{-3}\right)$ & 74,4 & 56,4 & 60,4 & 44,3 \\
\hline$\vee \%$ & 3 & 8 & 4 & 5 \\
\hline $\mathrm{m} \%$ & 83 & 69 & 81 & 80 \\
\hline $\mathrm{B}\left(\mathrm{mg} \mathrm{dm}^{-3}\right)$ & 0,16 & 0,15 & 0,16 & 0,15 \\
\hline $\mathrm{Cu}\left(\mathrm{mg} \mathrm{dm}^{-3}\right)$ & 0,6 & 0,7 & 0,7 & 0,7 \\
\hline $\mathrm{Fe}\left(\mathrm{mg} \mathrm{dm}^{-3}\right)$ & 102 & 76 & 74 & 40 \\
\hline $\mathrm{Mn}\left(\mathrm{mg} \mathrm{dm^{-3 }}\right)$ & 2,0 & 0,8 & 0,7 & 0,6 \\
\hline $\mathrm{Zn}\left(\mathrm{mg} \mathrm{dm}^{-3}\right)$ & 0,3 & 0,3 & 0,3 & 0,3 \\
\hline
\end{tabular}

\subsection{Calagem}

Dois meses antes da instalação do experimento foi realizada uma aplicação de calcário dolomítico em área total, na dosagem de $1,7 \mathrm{t} \mathrm{ha}^{-1}$, sem incorporação.

\subsection{Adubação}

\subsubsection{Adubação de plantio}

A adubação de plantio foi comum a todos os tratamentos e consistiu na aplicação de $90 \mathrm{~kg}$ de $\mathrm{P}_{2} \mathrm{O}_{5} \mathrm{ha}^{-1}$ na forma de superfosfato triplo, aplicado no sulco de plantio. 


\subsubsection{Adubação de cobertura}

A adubação nitrogenada e potássica foi comum à todos os tratamentos, com as doses parceladas em duas aplicações. Aos 2 meses após o plantio, foram aplicados $20 \mathrm{~kg} \mathrm{~N} \mathrm{ha}^{-1}$ e $40 \mathrm{~kg} \mathrm{~K}_{2} \mathrm{O}$ ha $^{-1}$, correspondente a $30 \%$ da dose total e os $70 \%$ restante foram aplicados aos 9 meses após o plantio com $40 \mathrm{~kg}$ $\mathrm{N}$ ha ${ }^{-1}$ e $80 \mathrm{~kg}$ de $\mathrm{K}_{2} \mathrm{O} \mathrm{ha}^{-1}$. As fontes utilizadas foram o sulfato de amônio e o cloreto de potássio. As aplicações foram feitas a uma distância de $40-50 \mathrm{~cm}$ do caule da planta, em cobertura sobre a superfície do solo, sem incorporação.

Juntamente com o nitrogênio e o potássio, aos 2 meses de idade, foram aplicados $2 \mathrm{~kg}$ de $\mathrm{Zn} \mathrm{ha}{ }^{-1}$ e $1 \mathrm{~kg}$ de $\mathrm{Cu} \mathrm{ha}^{-1}$, na forma de sulfato de zinco e sulfato de cobre, respectivamente.

\subsubsection{Adubação boratada}

O boro foi aplicado juntamente com os adubos potássicos e nitrogenados, sendo $30 \%$ da dose total aplicada aos 2 meses após o plantio e os $70 \%$ restante aos 9 meses após o plantio. O produto utilizado como fonte de $\mathrm{B}$ foi o Bórax (11\% B) e as doses foram de $0 ; 0,5 ; 1 ; 2 ; 4$ e $8 \mathrm{~kg} \mathrm{~B} \mathrm{ha}^{-1}$.

\subsection{Avaliação, colheita e preparo do material vegetal para a análise química}

A avaliação do estado nutricional foi realizada aos 12 e 24 meses após o plantio através da coleta de três tipos de folhas (nova, velha e diagnóstico) de ramos situados na região mediana das árvores.

As folhas novas corresponderam as 4 primeiras folhas localizadas nos ramos a partir do ápice, as folhas diagnóstico ao $5^{\mathrm{a}}$ e $6^{\mathrm{a}}$ pares de folhas e as folhas velhas àquelas situadas abaixo da $6^{\text {a }}$ folha. Depois de coletado o material foi acondicionado em saco de papel e colocado em estufa de 
circulação forçada de ar, com temperatura média de $65^{\circ} \mathrm{C}$, até atingir peso constante. A moagem do material foi feita em moinho tipo Willey de acordo com instruções de Malavolta et al. (1997c).

A coleta de folhas, aos 12 meses de idade, foi realizada no final da estação chuvosa, nesse período (outubro a dezembro) foi registrado um excedente de $337,2 \mathrm{~mm}$, na região de Itatinga - SP. Aos 24 meses de idade, a coleta de folhas foi realizada no final do período de seca, o qual apresentou entre os meses de julho e setembro, um déficit hídrico de $30 \mathrm{~mm}$.

\subsection{Análise química do material vegetal}

As amostras secas e moídas, foram submetidas a digestão sulfúrica $(\mathrm{N})$, nitro-perclórica (P; K; Ca; Mg; S; Cu; Fe; Mn; Zn) e por via seca (B) para obtenção dos extratos, visando a determinação dos macro e micronutrientes.

As determinações dos macro e micronutrientes contidos no material vegetal foram realizadas conforme metodologia descrita por Malavolta et al. (1997c). 


\subsection{Avaliação do crescimento}

Aos 12 meses de idade, foram realizadas medições de DAP e altura das 28 árvores úteis. Foram escolhidas sistematicamente sete árvores de cada parcela para coleta de folhas (Figura 2).

$\begin{array}{llllllll}0 & 0 & 0 & 0 & 0 & 0 & 0 & 0 \\ 0 & 0 & 0 & 0 & 0 & 0 & 0 & 0 \\ 0 & 0 & x & x & x & \underline{x} & 0 & 0 \\ 0 & 0 & x & x & x & \underline{x} & 0 & 0 \\ 0 & 0 & x & x & \underline{x} & x & 0 & 0 \\ 0 & 0 & x & x & x & x & 0 & 0 \\ 0 & 0 & x & \underline{x} & x & x & 0 & 0 \\ 0 & 0 & \underline{x} & x & x & x & 0 & 0 \\ 0 & 0 & \underline{x} & x & x & x & 0 & 0 \\ 0 & 0 & 0 & 0 & 0 & 0 & 0 & 0 \\ 0 & 0 & 0 & 0 & 0 & 0 & 0 & 0\end{array}$

Figura 2 - Esquema da escolha das árvores para coleta de folhas $(X=$ plantas úteis $\mathrm{O}=$ bordadura da parcela $\underline{X}=$ árvores que tiveram as folhas coletadas).

Aos 24 meses de idade, foram realizadas medições de DAP e altura somente de 10 árvores úteis de cada parcela. A seleção dessas árvores foi feita de maneira sistemática (Figura 3), procurando sempre evitar árvores atípicas ou defeituosas (bifurcadas, trifurcadas ou retorcidas). 


$\begin{array}{llllllll}0 & 0 & 0 & 0 & 0 & 0 & 0 & 0 \\ 0 & 0 & 0 & 0 & 0 & 0 & 0 & 0 \\ 0 & 0 & \underline{0} & x & x & \underline{0} & 0 & 0 \\ 0 & 0 & x & \underline{0} & x & x & 0 & 0 \\ 0 & 0 & x & x & \underline{0} & x & 0 & 0 \\ 0 & 0 & \underline{0} & x & x & x & 0 & 0 \\ 0 & 0 & x & x & \underline{0} & \underline{0} & 0 & 0 \\ 0 & 0 & \underline{0} & \underline{0} & x & x & 0 & 0 \\ 0 & 0 & x & x & \underline{0} & x & 0 & 0 \\ 0 & 0 & 0 & 0 & 0 & 0 & 0 & 0 \\ 0 & 0 & 0 & 0 & 0 & 0 & 0 & 0\end{array}$

Figura 3 - Esquema da escolha das árvores que tiveram o DAP e altura medidos. $(X=$ plantas úteis $\mathrm{O}=$ bordadura da parcela $\underline{\mathrm{O}}=$ árvores escolhidas para medição do DAP e altura).

Entre as árvores que tiveram o DAP e altura medidos, foram escolhidas e abatidas 3 árvores ao acaso para coleta de folhas e de caule para análise da qualidade da madeira.

\subsection{Características da madeira}

De cada árvore, foi retirado um disco na altura do DAP de aproximadamente $4 \mathrm{~cm}$ de espessura. Cada disco foi dividido em 4 partes, sendo duas destinadas para análise física e uma para análise anatômica da madeira.

\subsubsection{Análise anatômica}

Da madeira contida no lenho, foram cortados pequenos palitos e colocados em tubos de ensaio, adicionando-se água destilada, para facilitar a difusão da solução macerante. Em seguida, retirou-se a água dos tubos e adicionou-se a solução macerante ( 5 partes de ácido acético para 1 parte de 
ácido nítrico; diluindo a mistura de ácidos em água destilada na proporção de $1: 2$ ), cobrindo todo o material. A maceração foi realizada em banho-maria, sob ebulição, dentro da capela com exaustor, durante aproximadamente 40 minutos. Logo após, esgotou-se a solução macerante e o material foi lavado várias vezes em água corrente, com posterior armazenamento em água até o preparo das lâminas (Barrichelo \& Foelkel, 1983).

A partir do material macerado, foram montadas duas lâminas para cada tratamento, e mensurados os parâmetros de 30 fibras: comprimento $(\mathrm{mm})$, a largura $(\mu \mathrm{m})$, o diâmetro do lume $(\mu \mathrm{m})$ e a espessura da parede das fibras $(\mu \mathrm{m})$. A espessura da parede $(E)$ foi calculada como a metade da diferença entre a largura da fibra $(L)$ e o diâmetro do lume $(D L)$, conforme a fórmula $E=(L-D L) / 2$. A fração parede foi calculada pela seguinte expressão: $(E P \times 2 / L F) \times 100$, onde $E P=$ espessura da parede das fibras e $L F=$ largura das fibras.

Para coloração usou-se uma gota de corante safranina na lâmina misturado com a suspensão.

\subsubsection{Análise física}

O conceito da densidade básica define-se como sendo a relação entre a massa absolutamente seca da amostra de madeira e seu volume saturado. As cunhas foram imersas em água até atingirem a saturação completa. A seguir foi empregado o método da balança hidrostática (Norma ABCP M14/70), que consiste em determinar o peso imerso, peso úmido e peso absolutamente seco da amostra.

O cálculo da densidade básica foi feito através da seguinte expressão:

$d_{b}=P S / P U-P I$

onde: $\quad d_{b}=$ densidade básica, em $\mathrm{g} \mathrm{cm}^{-3}$

PS = peso absolutamente seco da amostra, em g

$\mathrm{PU}=$ peso úmido da amostra, em $\mathrm{g}$

$\mathrm{PI}=$ peso imerso, em $\mathrm{g}$. 


\subsection{Avaliação da qualidade do fuste}

Aos 12 meses de idade, avaliou-se a qualidade do fuste das árvores úteis de cada parcela. Essa avaliação foi feita com base na porcentagem de árvores bifurcadas e trifurcadas, além da porcentagem de árvores mortas.

\subsection{Geada}

Apesar de se tratar de um fenômeno climático esporádico, foi registrado na região de Itatinga, em 2000, a ocorrência de 5 geadas. O período de ocorrência foi de 23 de junho a 26 de julho e a temperatura mínima atingida foi de $-4^{\circ} \mathrm{C}$.

\subsubsection{Avaliação dos danos causados pela geada}

Aos 40 dias após a última geada, foi feita uma avaliação do efeito sobre os clones de E. grandis. Foram avaliadas as 28 árvores úteis de cada parcela. O método utilizado foi o proposto por Lisbão Júnior (1986), o qual consiste na classificação das mudas em níveis de incidência. Os níveis utilizados foram: nivel $1=100 \%$ afetada; nível $2=75 \%$ a $100 \%$ afetada; nível $3=50 \%$ a $75 \%$ afetada, nível $4=$ menos de $50 \%$ afetada e nivel $5=0 \%$ afetada. Os níveis $1 \mathrm{e}$ 2 foram agrupados e reclassificados como porcentagem de árvores severamente afetadas e aquelas com niveis 3,4 e 5, como porcentagem de árvores ligeiramente afetadas. 


\section{RESULTADOS E DISCUSSÃO}

\subsection{Sintomas visuais}

\subsubsection{Deficiência de boro}

Os primeiros sintomas de deficiência surgiram aos 150 dias após o plantio nas doses de 0 e $0,5 \mathrm{~kg}$ de $\mathrm{B} \mathrm{ha}{ }^{-1}$. Até essa data, as plantas do tratamento de $0,5 \mathrm{~kg}$ de $\mathrm{B} \mathrm{ha}{ }^{-1}$ tinham sido adubadas com $30 \%$ da dose total. Os sintomas foram caracterizados por folhas com margens cloróticas, folhas mal formadas, seca de ponteiro seguida de bifurcação do tronco e algumas árvores apresentaram quebra de ponteiro (Figura 4).

Os sintomas se assemelham aos descritos por Tokeshi et al. (1976), Dell e Malajaczuk (1994) e Silveira et al. (1995). 
A

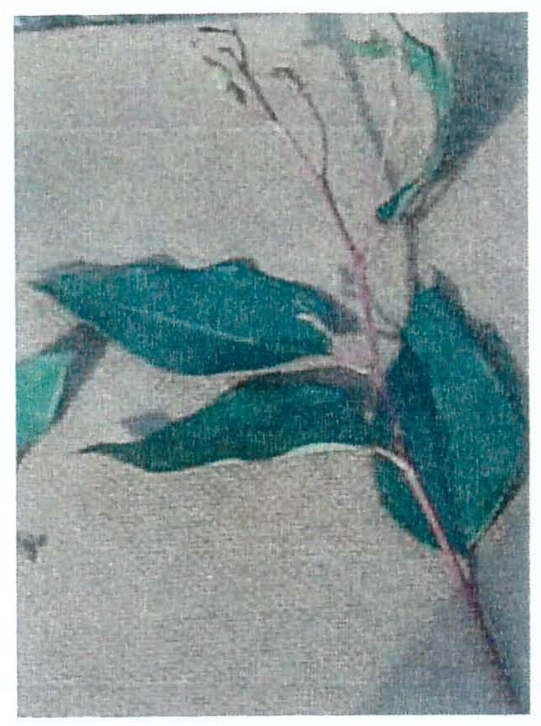

D

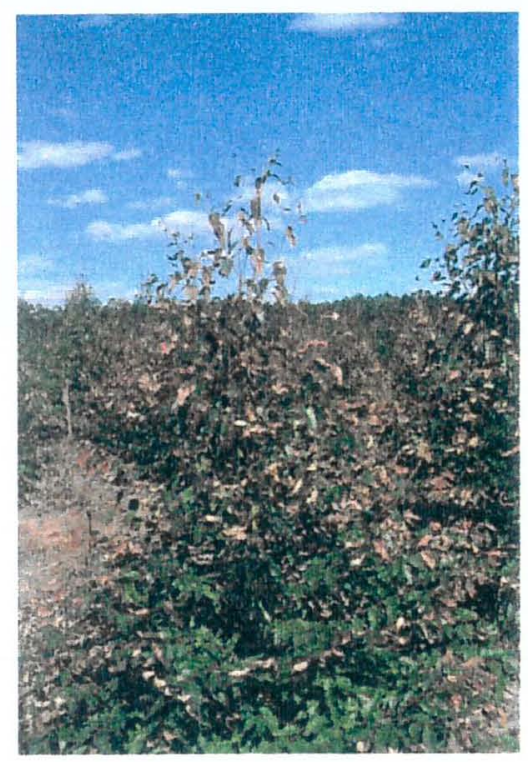

B

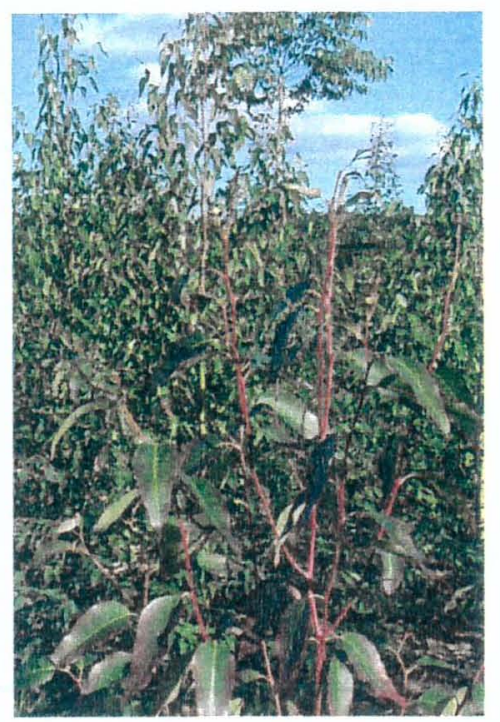

C

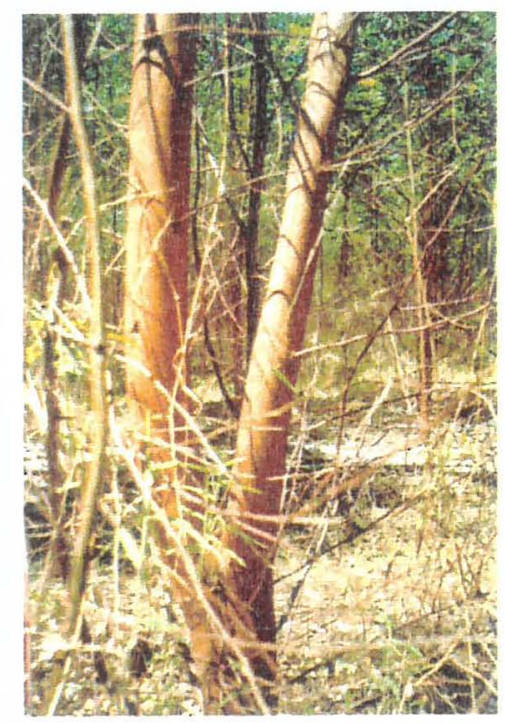

$\mathrm{E}$

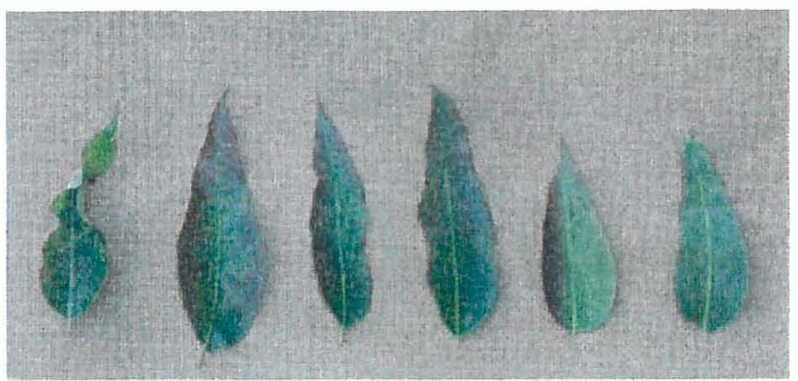

Figura 4 - Sintomas de deficiência de boro. A: Morte da gema apical no clone. A1. B: Seca de ponteiro no clone A1. C: Seca de ponteiro e bifurcação do tronco no clone A2. D: Seca de ponteiro no clone A2. E: Clone A1 com folhas novas pequenas, deformadas e avermelhadas. 


\subsection{Avaliação do crescimento das plantas}

\subsubsection{Altura}

Houve efeito significativo dos clones de E. grandis e das doses de boro sobre a altura. A altura do clone $A 1$ foi superior em $14 \%$ e $9,7 \%$ em relação a do clone $\mathrm{A} 2$, aos 12 e 24 meses de idade, respectivamente (Tabela 4).

Observou-se efeito das doses de boro sobre a altura dos clones. Os materiais genéticos responderam de forma diferenciada ao aumento das doses (Figura 5). O ganho em altura do clone $A 1$, com a aplicação de boro, foi superior ao ganho alcançado pelo clone A2. Os clones A1 e A2 tiveram, respectivamente, na dose de $0,5 \mathrm{~kg}$ de $\mathrm{B} \mathrm{ha} \mathrm{h}^{-1}$ aumentos de $48 \%$ e $18 \%$ na altura em relação à testemunha, aos 12 meses de idade e de $27 \%$ e $17 \%$, aos 24 meses de idade.

Resultados semelhantes foram observados por Sgarbi \& Silveira (1999) em eucalipto, na região de Três-Marias (MG), onde a aplicação de 2,2 kg de $B$ $\mathrm{ha}^{-1}$ promoveu ganhos de até $17 \%$ em altura. Em Portugal, nas regiões de Vila Real e Castelo Banco, a aplicação de boro em Eucalyptus globulus proporcionou um aumento na altura média das árvores de 26,6 \% e 93,2\%, respectivamente, aos 12 meses de idade. Sendo o solo da região de Castelo Branco mais arenoso que o solo de Vila Real (Coutinho et al., 1995). A deficiência de boro é comum em solos de baixa fertilidade natural, como os solos arenosos, onde os nutrientes minerais se encontram em niveis limitantes. Esse tipo de solo contem baixos teores de matéria orgânica, principal fonte de boro nos solos tropicais, sendo o problema agravado por períodos de seca prolongada. A deficiência hídrica diminui a atividade dos microorganismos na mineralização da matéria orgânica, diminuindo a disponibilidade de boro (Malavolta e Kliemann, 1985).

A partir da dose de $4 \mathrm{~kg}$ de $B \mathrm{ha}^{-1}$ ocorreu decréscimo na altura das árvores do clone A2. A mesma tendência não foi verificada para o clone A1. 
Esse clone foi mais tolerante a doses elevadas de boro. Nota-se ainda que, para esse clone, não houve resposta em altura para doses superiores a $1 \mathrm{~kg}$ de $\mathrm{B} \mathrm{ha}^{-1}$.

Resultados semelhantes aos obtidos para o clone A2 foram verificados por Coutinho et al. (1995). Esses autores relataram que a aplicação de níveis elevados de boro em solos muito arenosos pode resultar no aparecimento, a curto prazo, de sintomas de fitotoxicidade. Os autores observaram esse efeito em ensaio com E. globulus em Portugal, quando se aplicou 2,2; 4,4 e 8,8 kg de boro $\mathrm{ha}^{-1}$. Essa fitotoxicidade provocou um efeito depressivo na altura para as doses de 4,4 e $8,8 \mathrm{~kg}$ de boro $\mathrm{ha}^{-1}$.

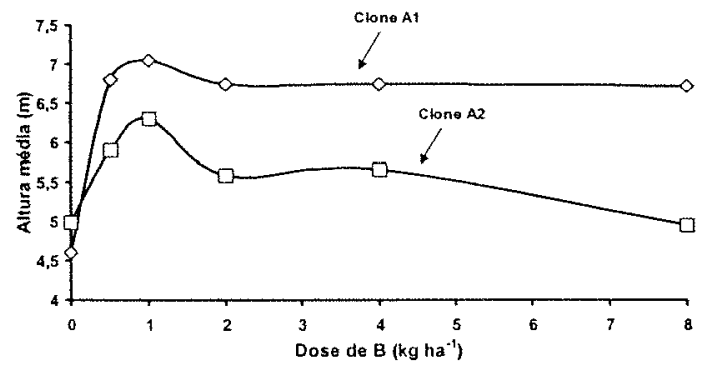

A

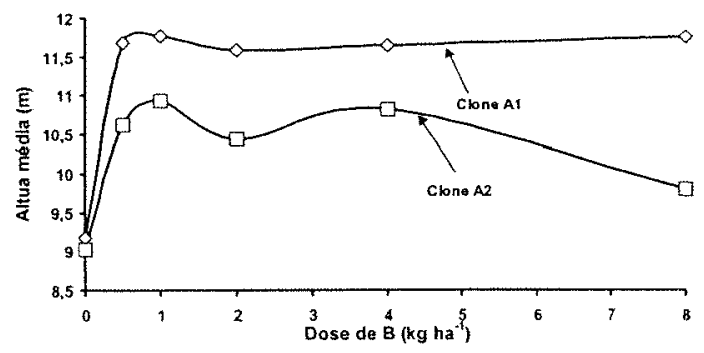

B

Figura 5 - A: Altura média do clone A1 e do clone A2, aos 12 meses de idade.

B: Altura média do clone A1 e do clone A2, aos 24 meses de idade.

\subsubsection{Diâmetro}

Em relação ao DAP, houve efeito significativo das doses de $\mathrm{B}$ e dos clones de E. grandis. O valor do DAP do clone A1 foi superior em $8 \%$ e $11 \%$ em relação ao clone $A 2$, aos 12 e 24 meses de idade, respectivamente (Tabela 4).

Igualmente ao que ocorreu para a altura, os clones tiveram comportamentos diferenciados em relação ao DAP com o aumento das doses de boro (Figura 6). Os clones A1 e A2 tiveram, respectivamente, na dose de 0,5 
$\mathrm{kg}$ de $\mathrm{B} \mathrm{ha}{ }^{-1}$ aumentos de $21 \%$ e $17 \%$ no DAP em relação à testemunha, aos 12 meses de idade e de $23 \%$ e $13 \%$, aos 24 meses de idade. A partir da dose de $1 \mathrm{~kg}$ de $B$ ha $^{-1}$, o clone A2 apresentou uma queda nos valores de DAP. Esse efeito, embora não significativo, foi mais pronunciado aos 12 meses de idade.

Resposta positiva em DAP com a aplicação de boro, em eucalipto, também foi obtido por Giovanetti (1999), em latossolo textura arenosa, na região de Lençóis Paulista. A adição de $2,8 \mathrm{~kg} \mathrm{~B} \mathrm{ha}^{-1}$ proporcionou um aumento de $9 \%$ no DAP em relação à testemunha, aos 2,5 anos de idade. O mesmo foi observado por Coutinho et al. (1995) na região de Vila Flor em Portugal. A aplicação de boro promoveu ganho em DAP da ordem de $36,8 \%$ em relação a testemunha.

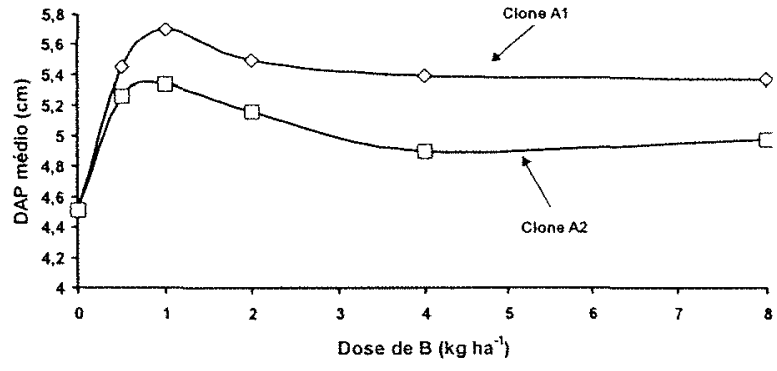

A

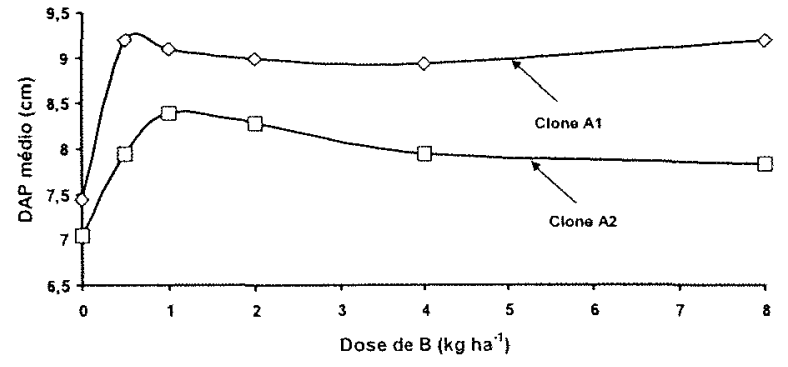

B

Figura 6 - A: DAP médio do clone $A 1$ e do clone $A 2$, aos 12 meses de idade. $B$ : DAP médio do clone $A 1$ e do clone $A 2$, aos 24 meses de idade.

\subsubsection{Volume cilíndrico de madeira}

Houve efeito das doses de boro e dos clones em relação ao volume. Independente da dose de boro aplicada, o maior volume foi observado no clone A1. Esse clone apresentou um volume $73 \%$ e $33 \%$ superior ao clone A2, aos 12 e 24 meses de idade, respectivamente (Tabela 4). 
O clone $A 1$ apresentou, em relação ao clone $A 2$, maior ganho em volume com a aplicação de boro. O ganho de produtividade para o clone A1 e o clone $\mathrm{A} 2$, com a aplicação de $0,5 \mathrm{~kg}$ de $\mathrm{B} \mathrm{ha}^{-1}$ foi, respectivamente, de $281 \% \mathrm{e}$ $78 \%$, aos 12 meses de idade e de $94 \%$ e $42 \%$, aos 24 meses de idade.

Para doses superiores a $0,5 \mathrm{~kg}$ de $B$ ha $^{-1}$ não houve diferença significativa no volume de madeira do clone A1. Para o clone A2 houve decréscimo a partir da aplicação de $1 \mathrm{~kg}$ de $B \mathrm{ha}^{-1}$, sendo que aos 12 meses de idade, a aplicação de $8 \mathrm{~kg}$ de $\mathrm{B} \mathrm{ha}{ }^{-1}$ promoveu uma redução de $50,4 \%$ no volume cilíndrico em relação à ausência de boro (Figura 7).

Benedetti (1999) também observou perda de produtividade em plantações de eucalipto na região de Anhembi - SP. A dose de $4 \mathrm{~kg} \mathrm{~B} \mathrm{ha}^{-1}$ foi a que proporcionou maior crescimento em volume, aos 5 meses de idade. $O$ aumento do fornecimento de boro, 6 e $8 \mathrm{~kg} \mathrm{~B} \mathrm{ha}^{-1}$, promoveu perdas de produtividade da ordem de 7 e $20 \%$, respectivamente. Segundo o autor, altas doses de boro aplicadas na época chuvosa, podem causar fitotoxicidade ao eucalipto.

Cannon (1981) observou ganhos em volume para E. grandis, aos 4 anos de idade, com a aplicação de NPK + B quando comparado a aplicação de NPK sem B. Fonseca et al. (1990) também obtiveram para E. camaldulensis um ganho em volume de 25 a $32 \%$ em relação à testemunha, com a aplicação de 2,4 e $4,8 \mathrm{~kg}$ de $B \mathrm{ha}^{-1}$, na região de Brasilândia-MG, aos 30 meses de idade.

Tabela 4. Altura, diâmetro e volume cilíndrico dos clones de E. grandis.

\begin{tabular}{ccccc}
\hline Época & Clone & Altura $(\mathrm{m})$ & DAP $(\mathrm{cm})$ & Volume $_{\mathrm{c}}\left(\mathrm{m}^{3} \mathrm{ha}^{-1}\right)$ \\
\hline \multirow{2}{*}{12 meses } & Clone A1 & $6,4 \mathrm{a}$ & $5,4 \mathrm{a}$ & $25,4 \mathrm{a}$ \\
& Clone A2 & $5,6 \mathrm{~b}$ & $5,0 \mathrm{~b}$ & $14,6 \mathrm{~b}$ \\
\multirow{2}{*}{ meses } & Clone A1 & $11,3 \mathrm{a}$ & $8,8 \mathrm{a}$ & $116,8 \mathrm{a}$ \\
& Clone A2 & $10,3 \mathrm{~b}$ & $7,9 \mathrm{~b}$ & $87,5 \mathrm{~b}$ \\
\hline
\end{tabular}

Médias seguidas de mesma letras na vertical não diferem entre si pelo teste de Tukey ao nivel de $5 \%$ de probabilidade. 


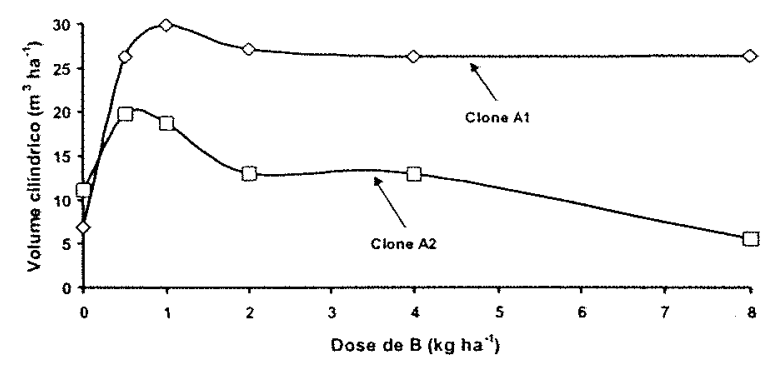

A

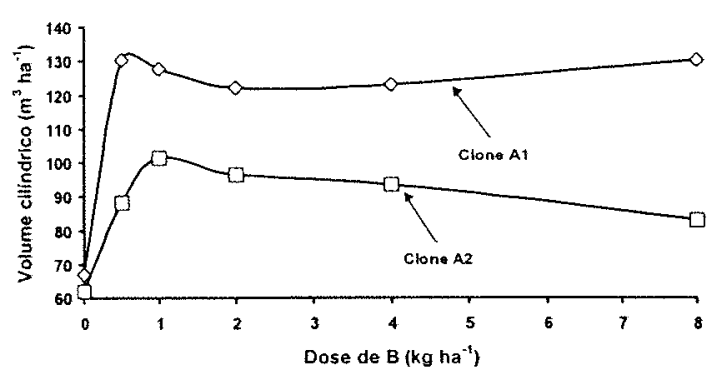

B

Figura 7-A: Volume cilíndrico total de madeira do clone $A 1$ e do clone $A 2$, aos 12 meses de idade. $B$ : Volume cilindrico total de madeira do clone $A 1$ e do clone $A 2$, aos 24 meses de idade.

\subsection{Estado nutricional dos clones de Eucalyptus grandis}

\subsubsection{Efeito dos clones na concentração dos macronutrientes}

Aos 12 meses de idade para os macronutrientes estudados, com exceção do potássio, constatou-se efeito dos clones nas concentrações foliares. As maiores concentrações foram observadas no clone A2, para os três tipos de folhas amostradas. Em relação ao potássio, houve diferença entre os clones somente para a concentração das folhas novas. Igualmente ao que ocorreu para os demais macronutrientes, a maior concentração de potássio nas folhas novas foi observada no clone A2 (Tabelas 5, 6 e 7).

Aos 24 meses de idade observou-se diferenças significativas entre os clones em relação a concentração de $\mathrm{N}, \mathrm{P}, \mathrm{Mg}$ e $\mathrm{S}$ nas folhas novas e folhas diagnóstico. As maiores concentrações para esses nutrientes foram encontradas no clone A1. Nas folhas velhas não houve diferença ente os clones para as concentrações de $\mathrm{N}, \mathrm{Mg}$ e S. Já para o fósforo houve diferença entre o clone $A 1$ e o clone $A 2$, com maior concentração no clone $A 1$. Os clones não diferiram em relação a concentração de cálcio e potássio nas folhas novas e diagnóstico. Para as folhas velhas, verificou-se que as maiores concentrações 
de $\mathrm{K}$ e $\mathrm{Ca}$ foram encontradas no clone $\mathrm{A} 2$, havendo diferença entre esse clone e o clone A1 (Tabelas 8, 9 e 10).

De modo geral, com o aumento da idade ocorreu uma redução na concentração dos macronutrientes. Segundo Vetorazzo (1989) a concentração dos nutrientes pode variar durante as épocas do ano, comparando-se folhas com a mesma idade fisiológica. As variações sazonais são as que mais influenciam o teor de nutrientes minerais nas árvores, principalmente em relação à $\mathrm{P}, \mathrm{K}, \mathrm{Ca}$ e $\mathrm{Mg}$, sendo que as maiores concentrações nas árvores ocorre no verão (Bellote, 1990). Já a variação no teor foliar dos nutrientes, entre os clones, pode ser resultante de diferentes exigências nutricionais da árvore em relação a idade. O desenvolvimento inicial do clone $A 1$, aos 12 meses de idade, foi superior ao do clone A2, sendo seu volume $73 \%$ maior. Com base nisso, o fato das maiores concentrações foliares para a maioria dos macronutrientes analisados estarem presentes no clone $A 2$, pode ser interpretado como efeito de concentração devido ao menor crescimento das árvores. No entanto, aos 24 meses de idade, o clone A2 apresentou menores concentrações de N, P Mg e S nas folhas diagnóstico em relação ao clone A1. Isso pode ser resultado do maior desenvolvimento das árvores dos 12 aos 24 meses de idade, uma vez que a diferença percentual em volume entre esse clone e o clone A1 foi reduzida para $33 \%$.

Tabela 5. Concentração dos macronutrientes nas folhas novas dos clones de Eucalyptus grandis, aos 12 meses de idade.

\begin{tabular}{ccccccc}
\hline Clone & $\mathrm{N}$ & $\mathrm{P}$ & $\mathrm{K}$ & $\mathrm{Ca}$ & $\mathrm{Mg}$ & $\mathrm{S}$ \\
& & \multicolumn{7}{c}{$\mathrm{g} \mathrm{kg}^{-1}$} \\
Clone A1 & $20,13 \mathrm{~b}$ & $1,37 \mathrm{~b}$ & $9,27 \mathrm{~b}$ & $4,33 \mathrm{~b}$ & $2,46 \mathrm{~b}$ & $1,27 \mathrm{~b}$ \\
Clone A2 & $23,17 \mathrm{a}$ & $1,79 \mathrm{a}$ & $10,80 \mathrm{a}$ & $5,36 \mathrm{a}$ & $2,72 \mathrm{a}$ & $1,38 \mathrm{a}$ \\
Média & 21,6 & 1,6 & 10,1 & 4,8 & 2,6 & 1,3 \\
\hline
\end{tabular}

Médias seguidas de mesma letra não diferem entre si pelo teste de Tukey ao nivel de $5 \%$ de probabilidade. 
Tabela 6. Concentração dos macronutrientes nas folhas diagnóstico dos clones de Eucalyptus grandis, aos 12 meses de idade.

\begin{tabular}{|c|c|c|c|c|c|c|}
\hline Clone & \multirow{2}{*}{\multicolumn{6}{|c|}{$\frac{\mathrm{g} \mathrm{kg}^{-1}}{\text { Folhas diagnóstico }}$}} \\
\hline & & & & & & \\
\hline Clone A1 & $20,52 \mathrm{~b}$ & $1,67 b$ & $6,84 a$ & $5,04 \mathrm{~b}$ & $2,31 \mathrm{~b}$ & $1,36 \mathrm{~b}$ \\
\hline Clone A2 & $22,30 a$ & $1,99 \mathrm{a}$ & $7,18 \mathrm{a}$ & $6,69 \mathrm{a}$ & $2,48 a$ & $1,48 a$ \\
\hline Média & 21,4 & 1,9 & 7,1 & 5,9 & 2,4 & 1,5 \\
\hline
\end{tabular}

Tabela 7. Concentração dos macronutrientes nas folhas velhas dos clones de Eucalyptus grandis, aos 12 meses de idade.

\begin{tabular}{ccccccc}
\hline Clone & $\mathrm{N}$ & $\mathrm{P}$ & $\mathrm{K}$ & $\mathrm{Ca}$ & $\mathrm{Mg}$ & $\mathrm{S}$ \\
\hline \multirow{7}{*}{$\mathrm{g} \mathrm{kg}^{-1}$} & \multicolumn{7}{c}{ Folhas velhas } \\
Clone A1 & $18,14 \mathrm{~b}$ & $0,97 \mathrm{~b}$ & $7,16 \mathrm{a}$ & $6,92 \mathrm{~b}$ & $2,71 \mathrm{~b}$ & $1,16 \mathrm{~b}$ \\
Clone A2 & $20,44 \mathrm{a}$ & $1,25 \mathrm{a}$ & $6,79 \mathrm{a}$ & $9,83 \mathrm{a}$ & $3,27 \mathrm{a}$ & $1,32 \mathrm{a}$ \\
Média & 19,3 & 1,2 & 7,0 & 8,4 & 3,0 & 1,3 \\
\hline
\end{tabular}

Médias seguidas de mesma letra não diferem entre si pelo teste de Tukey ao nivel de $5 \%$ de probabilidade.

Tabela 8. Concentração dos macronutrientes nas folhas novas dos clones de Eucalyptus grandis, aos 24 meses de idade.

\begin{tabular}{ccccccc}
\hline Clone & $\mathrm{N}$ & $\mathrm{P}$ & $\mathrm{K}$ & $\mathrm{Ca}$ & $\mathrm{Mg}$ & $\mathrm{S}$ \\
& & \multicolumn{7}{c}{$\mathrm{g} \mathrm{kg}^{-1}$} \\
Clone A1 & $19,07 \mathrm{a}$ & $1,45 \mathrm{a}$ & $7,41 \mathrm{a}$ & $3,70 \mathrm{a}$ & $3,03 \mathrm{a}$ & $1,41 \mathrm{a}$ \\
Clone A2 & $17,25 \mathrm{~b}$ & $1,30 \mathrm{~b}$ & $7,83 \mathrm{a}$ & $4,00 \mathrm{a}$ & $2,75 \mathrm{~b}$ & $1,18 \mathrm{~b}$ \\
Média & 18,2 & 1,4 & 7,6 & 3,8 & 2,9 & 1,3 \\
\hline
\end{tabular}

Médias seguidas de mesma letra não diferem entre si pelo teste de Tukey ao nível de $5 \%$ de probabilidade. 
Tabela 9. Concentração dos macronutrientes nas folhas diagnóstico dos clones de Eucalyptus grandis, aos 24 meses de idade.

\begin{tabular}{|c|c|c|c|c|c|c|}
\hline Clone & \multirow{2}{*}{\multicolumn{6}{|c|}{$\frac{\mathrm{g} \mathrm{kg}^{-1}}{\text { Folhas diaqnóstico }}$}} \\
\hline & & & & & & \\
\hline Clone A1 & $18,94 a$ & $1,03 a$ & $5,69 a$ & $3,84 \mathrm{a}$ & $2,78 a$ & $1,10 a$ \\
\hline Clone A2 & $17,11 \mathrm{~b}$ & $0,93 \mathrm{~b}$ & $5,71 a$ & $4,21 a$ & $2,44 b$ & $0,86 \mathrm{~b}$ \\
\hline Média & 18,0 & 0,98 & 5,7 & 4,0 & 2,6 & 0,98 \\
\hline
\end{tabular}

Tabela 10. Concentração dos macronutrientes nas folhas velhas dos clones de Eucalyptus grandis, aos 24 meses de idade.

\begin{tabular}{ccccccc}
\hline Clone & $\mathrm{N}$ & $\mathrm{P}$ & $\mathrm{K}$ & $\mathrm{Ca}$ & $\mathrm{Mg}$ & $\mathrm{S}$ \\
& & \multicolumn{7}{c}{$\mathrm{g} \mathrm{kg}^{-1}$} & \multicolumn{7}{c}{ Folhas velhas } \\
Clone A1 & $16,33 \mathrm{a}$ & $0,93 \mathrm{a}$ & $4,56 \mathrm{~b}$ & $5,42 \mathrm{~b}$ & $2,65 \mathrm{a}$ & $0,96 \mathrm{a}$ \\
Clone A2 & $16,46 \mathrm{a}$ & $0,87 \mathrm{~b}$ & $4,98 \mathrm{a}$ & $7,08 \mathrm{a}$ & $2,57 \mathrm{a}$ & $0,92 \mathrm{a}$ \\
Média & 16,4 & 0,9 & 4,8 & 6,3 & 2,6 & 0,94 \\
\hline
\end{tabular}

Médias seguidas de mesma letra não diferem entre si pelo teste de Tukey ao nível de $5 \%$ de probabilidade.

Sem considerar os efeitos das doses de boro sobre as concentrações dos macronutrientes nas folhas diagnóstico, observou-se que aos 12 meses de idade as concentrações de $N$ e $P$ estavam dentro da faixa considerada adequada por Silveira et al. (1999). A concentração de K, Ca e Mg para o dois clones estava abaixo da faixa considerada adequada por esse autor. As concentrações de $S$ estavam próximas da faixa considerada adequada por Silveira et al. (1999).

Em relação as concentrações dos macronutrientes nas folhas diagnóstico, aos 24 meses de idade, observou-se que as concentrações de $N$, $\mathrm{P}, \mathrm{K}$ e Ca estavam bem abaixo da faixa considerada adequada por Silveira et al. (1999). Em relação ao $\mathrm{Mg}$, a concentração obtida para o clone A1 estava no limite superior e a do clone A2 no limite inferior da faixa considerada adequada por Silveira et al. (1999). As concentrações de $S$ estavam dentro da faixa considerada deficiente por esse autor. 


\subsubsection{Efeito dos clones na concentração dos micronutrientes}

Nos três tipos de folhas amostradas, aos 12 meses de idade, ocorreram diferenças significativas entre os clones para a concentração de $\mathrm{Mn}$ e $\mathrm{Zn}$. As maiores concentrações de $\mathrm{Mn}$ e $\mathrm{Zn}$ foram observadas no clone A2. Em relação ao $\mathrm{Cu}$ observou-se diferença significativa entre os clones para a concentração das folhas novas e das folhas diagnóstico, não havendo diferença nas folhas velhas. Já para a concentração de $\mathrm{Fe}$ a única diferença foi encontrada nas folhas novas. Igualmente ao $\mathrm{Mn}$ e ao $\mathrm{Zn}$, aos maiores concentrações de $\mathrm{Cu}$ e Fe foram observadas no clone A2 (Tabelas 11, 12 e 13).

Aos 24 meses de idade ocorreram diferenças significativas entre os clones para a concentração de $\mathrm{Mn}$. As maiores concentrações de $\mathrm{Mn}$ foram observadas no clone A2. Para o $\mathrm{Zn}$ houve diferença para os valores obtidos nas folhas diagnóstico e folhas velhas, não havendo diferença significativa nas folhas novas. Em relação ao $\mathrm{Cu}$ a única diferença foi encontrada nas folhas novas. Para o Fe houve diferença estatística entre os clones somente para as folhas velhas (Tabelas 14, 15 e 16)

Tabela 11. Concentração dos micronutrientes nas folhas novas dos clones de Eucalyptus grandis, aos 12 meses de idade.

\begin{tabular}{ccccc}
\hline Clone & Cu & Fe & $\mathrm{Mn}$ & $\mathrm{Zn}$ \\
& \multicolumn{4}{c}{$\mathrm{mg} \mathrm{kg}^{-1}$} \\
Clone A1 & $7,2 \mathrm{~b}$ & $36,1 \mathrm{~b}$ & $242,0 \mathrm{~b}$ & $15,4 \mathrm{~b}$ \\
Clone A2 & $9,2 \mathrm{a}$ & $45,4 \mathrm{a}$ & $279,0 \mathrm{a}$ & $22,3 \mathrm{a}$ \\
Média & 8,2 & 40,8 & 260,5 & 18,9 \\
\hline
\end{tabular}

Médias seguidas de mesma letra não diferem entre si pelo teste de Tukey ao nível de $5 \%$ de probabilidade. 
Tabela 12. Concentração dos micronutrientes nas folhas diagnóstico dos clones de Eucalyptus grandis, aos 12 meses de idade.

\begin{tabular}{ccccc}
\hline Clone & $\mathrm{Cu}$ & $\mathrm{Fe}$ & $\mathrm{Zn}$ \\
& \multicolumn{5}{c}{$\mathrm{mg} \mathrm{kg}^{-1}$} \\
\hline
\end{tabular}

Médias seguidas de mesma letra não diferem entre si pelo teste de Tukey ao nivel de $5 \%$ de probabilidade.

Tabela 13. Concentração dos micronutrientes nas folhas velhas dos clones de Eucalyptus grandis, aos 12 meses de idade.

\begin{tabular}{ccccc}
\hline Clone & $\mathrm{Cu}$ & $\mathrm{Fe}$ & $\mathrm{Mn}$ & $\mathrm{Mn}$ \\
& \multicolumn{5}{c}{$\mathrm{mg} \mathrm{kg}^{-1}$} \\
\hline Clone A1 & $8,4 \mathrm{a}$ & $56,1 \mathrm{a}$ & $378,2 \mathrm{~b}$ & $12,1 \mathrm{~b}$ \\
Clone A2 & $9,2 \mathrm{a}$ & $65,7 \mathrm{a}$ & $484,9 \mathrm{a}$ & $18,8 \mathrm{a}$ \\
Média & 8,8 & 60,9 & 431,6 & 15,4 \\
\hline
\end{tabular}

Médias seguidas de mesma letra não diferem entre si pelo teste de Tukey ao nível de $5 \%$ de probabilidade.

Tabela 14. Concentração dos micronutrientes nas folhas novas dos clones de Eucalyptus grandis, aos 24 meses de idade.

\begin{tabular}{ccccc}
\hline Clone & $\mathrm{Cu}$ & $\mathrm{Fe}$ & $\mathrm{Mn}$ & $\mathrm{Zn}$ \\
\hline & \multicolumn{4}{c}{$\mathrm{mg} \mathrm{kg}^{-1}$} \\
Clone A1 & $6,7 \mathrm{~b}$ & $79,1 \mathrm{a}$ & $134,6 \mathrm{~b}$ & $16,7 \mathrm{a}$ \\
Clone A2 & $7,3 \mathrm{a}$ & $62,0 \mathrm{a}$ & $191,8 \mathrm{a}$ & $17,6 \mathrm{a}$ \\
Média & 7,0 & 70,6 & 163,2 & 17,2 \\
\hline
\end{tabular}

Médias seguidas de mesma letra não diferem entre si pelo teste de Tukey ao nivel de $5 \%$ de probabilidade. 
Tabela 15. Concentração dos micronutrientes nas folhas diagnóstico dos clones de Eucalyptus grandis, aos 24 meses de idade.

\begin{tabular}{|c|c|c|c|c|}
\hline Clone & \multirow{2}{*}{\multicolumn{4}{|c|}{$\frac{\mathrm{mg} \mathrm{kg}^{-1}}{\text { Folhas diagnóstico }}$}} \\
\hline & & & & \\
\hline Clone A1 & $5,9 \mathrm{a}$ & $78,8 \mathrm{a}$ & $176,9 \mathrm{~b}$ & $13,8 b$ \\
\hline Clone A2 & $5,6 a$ & $67,4 a$ & 242,3 a & $16,8 \mathrm{a}$ \\
\hline Média & 5,8 & 73,1 & 209,6 & 15,3 \\
\hline
\end{tabular}

Médias seguidas de mesma letra não diferem entre si pelo teste de Tukey ao nível de $5 \%$ de probabilidade.

Tabela 16. Concentração dos micronutrientes nas folhas velhas dos clones de Eucalyptus grandis, aos 24 meses de idade.

\begin{tabular}{|c|c|c|c|c|}
\hline Clone & $\mathrm{Cu}$ & $\mathrm{Fe}$ & $\mathrm{Mn}$ & $\mathrm{Zn}$ \\
\hline & \multicolumn{4}{|c|}{$\begin{array}{c}\mathrm{mg} \mathrm{kg} \\
\text { Folhas velhas }\end{array}$} \\
\hline Clone A1 & $6,2 \mathrm{a}$ & $89,8 \mathrm{a}$ & $218,5 b$ & $12,0 \mathrm{~b}$ \\
\hline Clone A2 & $6,1 \mathrm{a}$ & $72,3 b$ & 355,0 a & $16,2 a$ \\
\hline Média & 6,15 & 81,0 & 286,8 & 14,1 \\
\hline
\end{tabular}

A concentração de Fe nas folhas diagnóstico, aos 12 meses de idade, estava abaixo da faixa considerada adequada por Silveira et al. (1999). Para esse autor as concentrações de $\mathrm{Cu}$ e $\mathrm{Mn}$ estavam dentro da faixa considerada adequada. A concentração de $\mathrm{Zn}$ para o clone A2 estava adequada de acordo com Silveira et al. (1999), já para o clone A1, a concentração do elemento encontrava-se abaixo do limite inferior da faixa considerada adequada.

A concentração de $M n$ nas folhas diagnóstico do clone $A 1$, aos 24 meses de idade, estava fora da faixa considerada adequada por Silveira et al. (1999), já para o clone $A 1$, a concentração de Mn estava dentro da faixa considerada adequada. A concentração de Fe para ambos os clones, estava adequada segundo essa autor. Em relação ao $\mathrm{Cu}$ os valores estavam no limite inferior da faixa considerada adequada por Silveira et al. (1999). Para esse autor, a concentração de $\mathrm{Zn}$ para o clone A2 encontrava-se dentro da faixa 
considerada adequada, já para o clone A1, a concentração de Zn estava abaixo da faixa considerada adequada.

\subsubsection{Relação entre a dose de boro aplicada e a concentração nas folhas}

O aumento das doses de boro aplicadas no solo proporcionou incrementos na concentração foliar dos dois clones (Figuras 8 e 9 ). Independente do clone, as maiores concentrações de B foram encontradas nas folhas velhas, seguidas pelas folhas diagnóstico e novas. Esse gradiente de concentração ocorre em função do grau de redistribuição do elemento na planta. Dependendo da mobilidade do elemento, a sua concentração pode ser maior ou menor conforme a posição das folhas no ramo. Isso explica o fato das maiores concentrações de boro terem sido encontradas nas folhas velhas, uma vez que ele é considerado imóvel dentro da planta (Malavolta et al. 1997).

A concentração de boro para ambos os clones variou em função da época de amostragem, havendo uma redução na concentração dos 12 para os 24 meses de idade (Tabelas 17 e 18). Sugere-se que as maiores concentrações de boro, aos 12 meses de idade para ambos os clones, ocorreram em função da coleta das folhas ter sido feita no final da estão chuvosa e aos 6 meses após a aplicação de $70 \%$ da dose total de boro. Aos 24 meses de idade, a coleta das folhas foi realizada no final da estação seca, período de baixa disponibilidade do nutriente, e aos 14 meses após a última adubação.

Verificou-se efeito dos clones para as concentrações foliares. As maiores concentrações nas folhas velhas e diagnóstico foram observadas no clone A1. Para as folhas novas, houve diferença entre os clones somente aos 24 meses de idade, sendo que a maior concentração foi encontrada no clone A2 (Tabela 18). Aos 24 meses, quando as plantas estavam passando pelo segundo período de seca, as folhas novas do clone A1apresentavam 63,3\% da concentração de boro das folhas velhas. Em relação ao clone $A 2$, a concentração de boro nas folhas novas foi $81 \%$ da encontrada nas folhas 
velhas. Isso sugere que o clone $A 2$, em condições de deficiência de boro, apresenta maior capacidade de translocar esse elemento. A capacidade de redistribuição do boro está ligada a quantidade de sorbitol produzida pela planta. Estudos recentes têm demonstrado que para espécies como o Prunus $s p$, Malus sp. e Pyrus $s p$, as quais produzem quantidades significativas de sorbitol, o boro é prontamente translocado no floema, mediante a formação de complexos B-sorbitol (Brown \& Hu,1996). Considerando que o boro é imóvel dentro da planta, a sua concentração deve ser sempre mais elevada em órgãos mais velhos (Brown \& Shelp, 1997), porém para espécies ricas em sorbitol, a concentração de boro nas folhas velhas é similar à concentração das folhas novas (Brown \& Hu, 1996). Essa mobilidade do boro no floema foi observada por Brown \& Shelp (1997) em plantas de brócolis e soja submetidas a condições de deficiência de boro. O gradiente de concentração do elemento, das folhas velhas para as folhas novas, desapareceu ou foi invertido, evidenciando que o boro possui mobilidade nessas plantas. Entretanto, não foram encontrados estudos relacionando a mobilidade de boro no floema de espécies de eucalipto.

Tabela 17. Concentração de boro nos diferentes tipos de folha dos clones de Eucalyptus grandis, aos 12 meses de idade.

\begin{tabular}{ccccc}
\hline Epoca & Clone & Folhas novas & $\begin{array}{c}\text { Folhas diagnóstico } \\
\mathrm{mg} \mathrm{kg}^{-1}\end{array}$ & Folhas velhas \\
\hline \multirow{2}{*}{12 meses } & Clone A1 & $33,2 \mathrm{a}(59,7)^{\circ}$ & $41,8 \mathrm{a}(75,2)$ & $55,6 \mathrm{a}(100)$ \\
& Clone A2 & $28,8 \mathrm{a}(61,5)$ & $34,2 \mathrm{~b}(73,1)$ & $46,8 \mathrm{~b}(100)$ \\
& Média & $31,0(60,5)$ & $38,0(74,2)$ & $51,2(100)$ \\
\hline
\end{tabular}

Médias seguidas de mesma letras na vertical não diferem entre si pelo teste de Tukey ao nível de $5 \%$ de probabilidade.

* Valores percentuais em relação aos valores encontrados nas folhas velhas. 
Tabela 18. Concentração de boro nos diferentes tipos de folha dos clones de Eucalyptus grandis, aos 24 meses de idade.

\begin{tabular}{ccccc}
\hline Época & Clone & Folhas novas & $\begin{array}{c}\text { Folhas diagnóstico } \\
\mathrm{mg} \mathrm{kg}^{-1}\end{array}$ & Folhas velhas \\
\hline \multirow{2}{*}{24 meses } & Clone A1 & $16,4 \mathrm{~b}(63,3)$ & $22,2 \mathrm{a}(85,7)$ & $25,9 \mathrm{a}(100)$ \\
& Clone A2 & $17,9 \mathrm{a}(81,0)$ & $19,2 \mathrm{~b}(86,9)$ & $22,1 \mathrm{~b}(100)$ \\
& Média & $17,2(71,7)$ & $20,7(86,2)$ & $24,0(100)$ \\
\hline
\end{tabular}

Médias seguidas de mesma letras na vertical não diferem entre si pelo teste de Tukey ao nivel de $5 \%$ de probabilidade.

* Valores percentuais em relação aos valores encontrados nas folhas velhas.

Aos 12 meses de idade a concentração de boro nas folhas diagnóstico para o clone A1 estava dentro da faixa considerada adequada por Silveira et al. (1999), já a concentração do clone A2 estava no limite inferior da faixa considerada adequada. Aos 24 meses de idade a concentração de boro nas folhas diagnóstico dos dois clones encontrava-se abaixo da faixa estabelecida como adequada para o desenvolvimento do E. grandis, segundo Silveira et al. (1999), a qual varia de 34 a $44 \mathrm{mg} \mathrm{de} \mathrm{B} \mathrm{kg}^{-1}$.
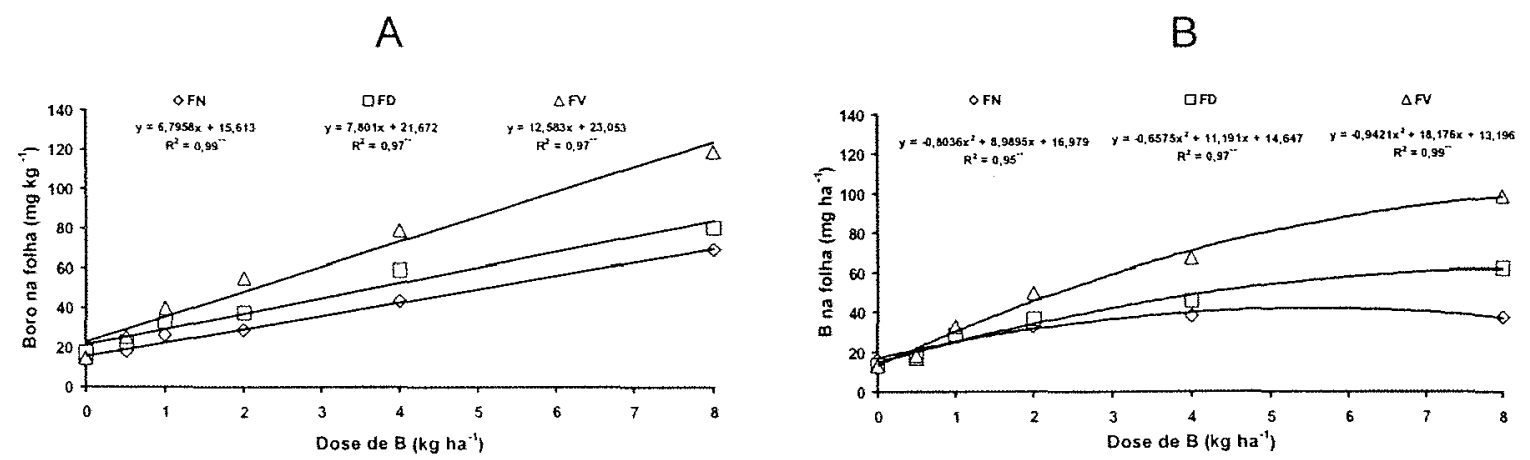

Figura 8 - A: Concentração de boro nos diferentes tipos de folhas do clone A1 em função das doses aos 12 meses de idade. B: Concentração de boro nos diferentes tipos de folhas do clone A2 em função das doses aos 12 meses de idade. 

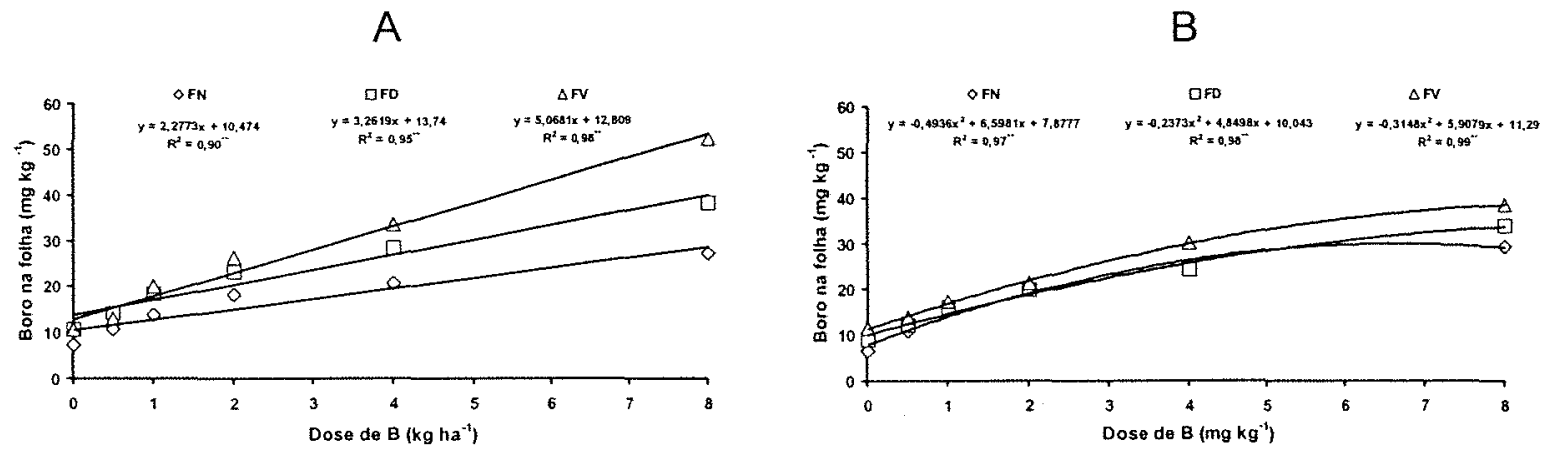

Figura 9 - A: Concentração de boro nos diferentes tipos de folhas do clone A1 em função das doses aos 24 meses de idade. B: Concentração de boro nos diferentes tipos de folhas do clone $A 2$ em função das doses aos 24 meses de idade.

Tabela 19. Concentração de boro nos diferentes tipos de folhas em função das doses.

\begin{tabular}{|c|c|c|c|c|}
\hline \multirow[t]{3}{*}{ Dose de B $\left(\mathrm{kg} \mathrm{ha}^{-1}\right)$} & \multicolumn{2}{|c|}{ Clone A1 } & \multicolumn{2}{|c|}{ Clone A2 } \\
\hline & \multicolumn{4}{|c|}{ Folha Nova $\left(\mathrm{mg} \mathrm{kg}^{-1}\right)$} \\
\hline & 12 meses & 24 meses & 12 meses & 24 meses \\
\hline 0 & 13,2 & 7,4 & 15,9 & 6,6 \\
\hline 0,5 & 18,1 & 10,7 & 19,2 & 10,8 \\
\hline 1 & 26,4 & 13,9 & 28,8 & 15,9 \\
\hline 2 & 28,6 & 18,2 & 32,7 & 19,9 \\
\hline 4 & 43,2 & 20,7 & 37,8 & 25,0 \\
\hline \multirow[t]{3}{*}{8} & 69,5 & 27,2 & 38,2 & 29,3 \\
\hline & \multicolumn{4}{|c|}{ Folha Diagnóstico $\left(\mathrm{mg} \mathrm{kg}^{-1}\right)$} \\
\hline & 12 meses & 24 meses & 12 meses & 24 meses \\
\hline 0 & 17,4 & 10,5 & 13,8 & 9,0 \\
\hline 0,5 & 23,15 & 14,3 & 17,0 & 12,1 \\
\hline 1 & 33,2 & 18,3 & 29,1 & 15,9 \\
\hline 2 & 37,6 & 23,2 & 36,9 & 19,9 \\
\hline 4 & 58,9 & 28,4 & 46,1 & 24,4 \\
\hline \multirow[t]{3}{*}{8} & 80,7 & 38,2 & 62,6 & 33,9 \\
\hline & \multicolumn{4}{|c|}{ Folha Velha $\left(\mathrm{mg} \mathrm{kg}^{-1}\right)$} \\
\hline & 12 meses & 24 meses & 12 meses & 24 meses \\
\hline 0 & 14,9 & 10,6 & 12,9 & 11,4 \\
\hline 0,5 & 25,5 & 12,9 & 18,3 & 13,9 \\
\hline 1 & 39,9 & 20,0 & 33,1 & 17,4 \\
\hline 2 & 55,3 & 26,3 & 50,1 & 21,3 \\
\hline 4 & 78,9 & 33,4 & 67,3 & 30,2 \\
\hline 8 & 118,9 & 52,3 & 98,9 & 38,4 \\
\hline
\end{tabular}


Observa-se que a concentração de boro diminui com o aumento da idade, havendo um efeito de diluição nas concentrações do elemento nos diferentes tipos de folhas para os dois clones (Tabela19).

A redução drástica na concentração de boro no período de 12 a 24 meses pode indicar que, para um ciclo de 7 anos, a aplicação de doses até $1 \mathrm{~kg}$ $\mathrm{ha}^{-1}$ seria adequada até os 24 meses de idade, e que para idades posteriores, talvez não fosse suficiente para atender a demanda de boro. Coutinho et al. (1995) sugeriram, a partir de ensaios desenvolvidos na região de Castelo Branco e Vila Flor, que a aplicação de $2,2 \mathrm{~kg}$ de $\mathrm{B}$ ha ${ }^{-1}$ foi suficiente para garantir o crescimento normal de árvores de E. globulus durante o primeiro ano após a sua aplicação. Entretanto, os autores também observaram que para os anos seguintes a aplicação dessa dose não foi suficiente para evitar problemas relacionados à deficiência do elemento.

\subsubsection{Relação entre concentração de boro nas folhas e o volume cilíndrico de madeira}

Os clones responderam de forma diferenciada em produtividade conforme variaram as concentrações de $\mathrm{B}$ nas folhas diagnóstico (Figura 10). $\mathrm{O}$ clone A2 pode ser considerado um clone de baixa exigência em boro. Porém não tolera altas concentrações do elemento nas folhas.

Aos 12 meses de idade o clone A2 apresentou pequena variação na produção relativa quando a concentração de boro nas folhas variou de 13 a 41 $\mathrm{mg} \mathrm{kg}^{-1}$. Esse clone apresentou queda de produtividade quando as concentrações foram superiores a $41 \mathrm{mg} \mathrm{de} \mathrm{B} \mathrm{kg}^{-1}$. O clone $\mathrm{A} 1$ foi considerado exigente em B. Para esse clone, o nível crítico ( $90 \%$ da máxima produção), abaixo do qual a produção fica limitada, foi de $35 \mathrm{mg}$ de $\mathrm{B} \mathrm{kg}^{-1}$ e a máxima produção foi obtida com $55,8 \mathrm{mg}$ de $\mathrm{B} \mathrm{kg}^{-1}$. 
A faixa adequada de $B$ nas folhas diagnóstico aos 12 meses de idade para o clone A1 e para o clone A2 foi, respectivamente de: 35 a $77 \mathrm{mg} \mathrm{kg}^{-1}$ e 13 a $41 \mathrm{mg} \mathrm{kg}^{-1}$.

Aos 24 meses de idade, a produção máxima do clone A1 e do clone A2 foi obtida quando as plantas apresentavam concentrações foliares de 29,3 e $22,8 \mathrm{mg}$ de $\mathrm{B} \mathrm{kg}^{-1}$, respectivamente. O nível para a obtenção de $90 \%$ da produção máxima foi de $18 \mathrm{mg}$ de $B \mathrm{~kg}^{-1}$ para o clone $\mathrm{A} 1$ e de $16 \mathrm{mg}$ de $\mathrm{B} \mathrm{kg}{ }^{-1}$ para o clone $A 2$. $A$ faixa adequada de $B$ nas folhas diagnóstico para o clone $A 1$ e $A 2$ variou de 18 e $38 \mathrm{mg}$ de $B \mathrm{~kg}^{-1}$ e 16 a $30 \mathrm{mg} \mathrm{de} B \mathrm{~kg}^{-1}$, respectivamente.

Silveira et al. (2000) verificaram que a faixa adequada de $B$ nas folhas, em povoamentos de $E$. saligna de alta produtividade, foi de 27 a $50 \mathrm{mg}$ de $B$ $\mathrm{kg}^{-1}$ e $90 \%$ da produção máxima foi alcançada quando as folhas apresentavam $25 \mathrm{mg}$ de $\mathrm{B} \mathrm{kg}^{-1}$. Valores esses acima dos obtidos no presente estudo para os dois clones analisados. 
A

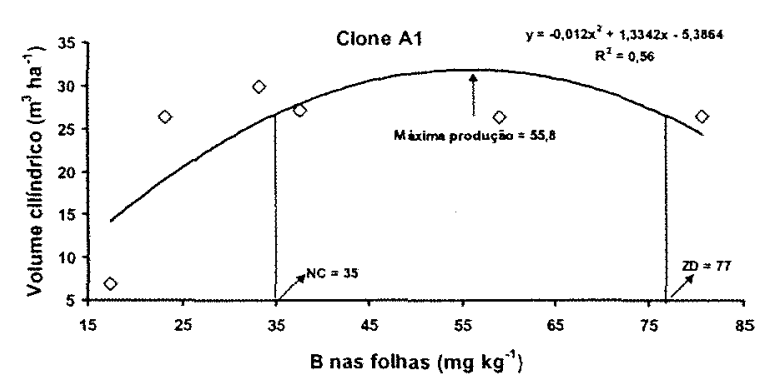

C

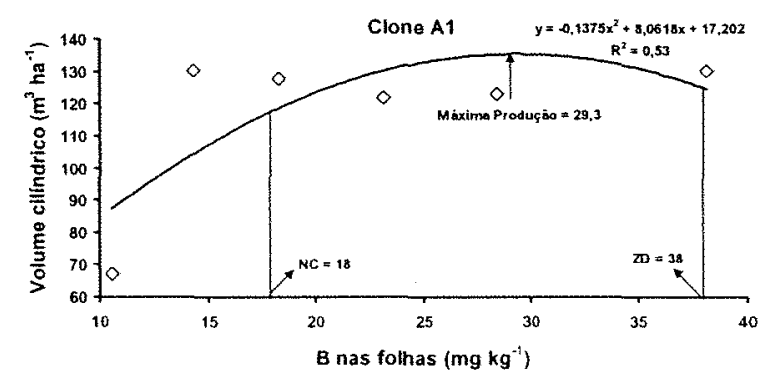

B

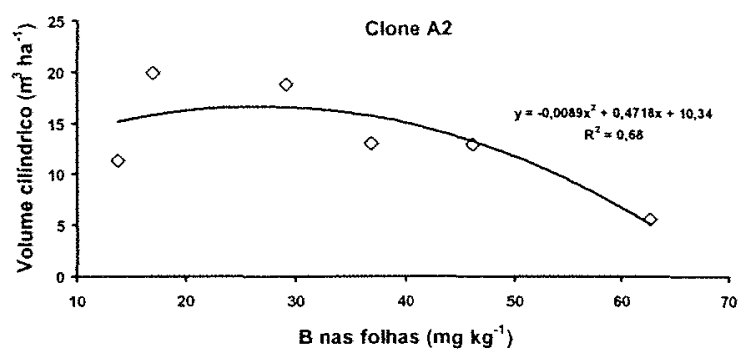

D

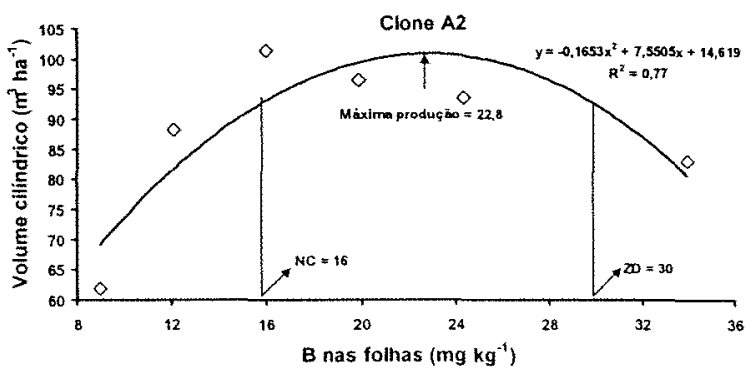

Figura 10 - A: Volume cilíndrico em função do teor de boro do clone A1 aos 12 meses de idade. B: Volume cilíndrico em função do teor de boro do clone $\mathrm{A} 2$ aos 12 meses de idade. C: Volume cilíndrico em função do teor de boro do clone A1 aos 24 meses de idade. D: Volume cilíndrico em função do teor de boro do clone $A 2$ aos 24 meses de idade.

\subsection{Qualidade da madeira}

\subsubsection{Densidade básica da madeira}

Para a densidade básica da madeira foi observado efeito somente dos clones de $E$. grandis, não havendo efeito das doses de boro aplicadas. O valor da densidade básica da madeira encontrado para o clone A2 foi $12,5 \%$ superior ao valor obtido para o clone A1 (Tabela 20). 
Provavelmente a diferença no valor da densidade básica entre os clones seja devido ao ritmo de crescimento. O aumento da taxa de crescimento de árvores de eucalipto tende a diminuir a densidade básica da madeira (Migliorini, 1986; Wilkins \& Horne, 1991; Wilkins \& Kitahara, 1991). Nos dois primeiros anos o ritmo de crescimento do clone $A 2$ foi inferior ao do clone $A 1$, consequentemente a madeira produzida nesse período foi mais densa. Ferreira et al. (1979) e Albino \& Tomazello Filho (1984) analisando o comportamento de várias espécies de eucalipto, observaram produção de madeira menos densa em regiões mais férteis, onde o ritmo de crescimento era maior. Outra hipótese estaria relacionada à fatores genéticos. As espécies produtoras de madeira possuem variações naturais em suas características que são provenientes de diferenças genotípicas e de diferentes respostas às condições nas quais as árvores estão se desenvolvendo (Vital, 1990).

Tabela 20. Densidade básica da madeira em função das doses de boro.

\begin{tabular}{ccc}
\hline Dose $\mathrm{B}\left(\mathrm{kg} \mathrm{ha}{ }^{-1}\right)$ & \multicolumn{2}{c}{ Densidade básica $\left(\mathrm{g} \mathrm{cm}^{-3}\right)$} \\
& Clone A1 & Clone A2 \\
\hline 0 & 0,402 & 0,450 \\
0,5 & 0,395 & 0,459 \\
1 & 0,399 & 0,449 \\
2 & 0,412 & 0,448 \\
4 & 0,404 & 0,447 \\
8 & 0,405 & 0,462 \\
Média & $0,403 \mathrm{a}$ & $0,452 \mathrm{~b}$ \\
\hline
\end{tabular}

Médias seguidas de mesma letra não diferem entre si pelo teste de Tukey ao nível de $5 \%$ de probabilidade.

A ausência do efeito da aplicação de boro sobre a densidade, pode ser explicado pelo fato de que, a fertilização afeta diretamente a atividade da copa e, indiretamente a formação de madeira (Jacob \& Balloni 1978). A mudança na atividade da copa, devido a alteração no estado nutricional do solo através do uso de fertilizantes, aumenta a superfície das folhas e consequentemente a produção de hormônios, os quais controlam a atividade cambial e a 
diferenciação do xilema (Siddiqui, 1972; Shimoyama \& Barrichelo, 1989). As adubações realizadas em povoamentos muito jovens, quando a copa ainda não está formada, têm pequeno efeito sobre as características da madeira. Somente depois da copa formada, é que esta apresentará efeito nas características das células do tronco (Megraw ${ }^{1}$, citado por Shimoyama \& Barrichelo, 1989).

Resultados semelhantes aos do presente estudo foram verificados por Andrade et al. (1994), esses autores não observaram diferenças significativas na densidade básica do cerne e do alburno das árvores de E. grandis, aos 6 anos de idade, submetidas à adubações fosfatada, sulfatada e a calagem. Mello (1968) também não observou efeito da adubação isolada de $\mathrm{N}, \mathrm{P}, \mathrm{K}$ e Ca e suas combinações na densidade da madeira de $E$. saligna, aos 2 anos de idade. Já Sgarbi et al. (2000) observaram que a carência de enxofre reduziu a densidade básica da madeira juvenil de $E$. grandis $\times$ E. urophylla, cultivada em solução nutritiva, em $11 \%$ em relação ao tratamento completo. A omissão de boro também proporcionou redução na densidade básica da madeira em relação ao tratamento completo, embora o efeito não tenha sido significativo.

\subsubsection{Parâmetros anatômicos: comprimento, largura, diâmetro do lume, espessura e fração parede}

Não foram observadas diferenças estatísticas para os parâmetros anatômicos analisados. As médias do comprimento, largura, diâmetro do lume, espessura e fração parede para cada clone em função das doses de boro estão nas Tabelas 21 e 22.

Apesar do boro estar envolvido na formação da parede celular (Hewitt \& Smith, 1975; Malavolta, 1980; Malavolta et al. 1997), e que na sua falta ocorrem modificações morfológicas, tais como parede celular muito fina e pouco lignificada (Lewis, 1980; Marschner, 1986, Malavolta et al., 1989), diminuindo

\footnotetext{
'MEGRAW, R.A. Wood quality factors in Loblolly pine. Atlanta, Tappi Press, 1985. 102p.
} 
assim a rigidez dos tecidos e causando uma desestruturação da parede celular (Trevizan, 2000), não foram observadas alterações nas características das fibras dos clones de E. grandis, aos 24 meses de idade, em função da aplicação de boro.

Talvez a ausência de modificações nas dimensões das fibras possa estar relacionada ao fato das amostras terem sido retiradas de um único ponto da árvore, ou seja, ao nível do $\mathrm{DAP}^{2}$ e terem sido analisadas de forma homogênea. Isso pode não ter revelado o efeito da deficiência de boro, uma vez que essa ocorre de forma sazonal, sendo mais intensa nos períodos de seca. Para estudos futuros envolvendo o boro e as características da madeira, sugere-se que as amostras sejam retiradas de diferentes alturas, como o proposto por Lima et al. (1992), ou seguindo a orientação medula-casca. Isso permitirá identificar se a deficiência de boro realmente afeta as características da madeira.

Sgarbi et al. (2000) observaram que a carência múltipla de K, B e Zn na solução nutritiva foi responsável pela redução de 22,47 para $16,85 \mu \mathrm{m}(25 \%)$ na largura e de 8,19 para 4,77 $\mu \mathrm{m}(42 \%)$ na espessura da parede das fibras da madeira juvenil de $E$. grandis $\times E$. urophylla, cultivadas em solução nutritiva, quando comparada ao tratamento completo. Os autores citam que nesse caso a diminuição da espessura da parede das fibras pode estar associada à carência de boro, uma vez que esse elemento é responsável pelo transporte e síntese de carboidratos. Porém, sugerem a realização de mais estudos nessa linha de pesquisa, principalmente em se tratando do gênero Eucalyptus.

\footnotetext{
${ }^{2}$ Essa padronização foi proposta por Nylinder em 1965, e considera o DAP, medido a 1,30m do solo, como padrão internacional usado em silvicultura (Albino \& Tomazello, 1985).
} 
Tabela 21. Comprimento, largura, espessura, diâmetro do lume e fração parede do clone A1 em função das doses de boro.

Dose B $\left(\mathrm{kg} \mathrm{ha}^{-1}\right)$
$\mathrm{C}^{*}(\mathrm{~mm})$
$\mathrm{L}(\mu \mathrm{m})$
$E(\mu \mathrm{m})$
$\mathrm{DL}(\mu \mathrm{m})$
FP $(\%)$

\begin{tabular}{cccccc}
\hline 0 & 0,953 & 20,48 & Clone $A 1$ \\
0,5 & 0,963 & 20,09 & 4,11 & 12,27 & 40 \\
1 & 1,020 & 20,36 & 4,96 & 12,17 & 39 \\
2 & 0,954 & 20,27 & 4,29 & 11,54 & 43 \\
4 & 0,998 & 20,31 & 3,94 & 11,69 & 42 \\
8 & 0,993 & 19,71 & 4,01 & 11,69 & 39 \\
\hline C = comprimento; L = largura; $\mathrm{E}=$ espessura da parede; $\mathrm{DL}=$ diâmetro do lume; FP = fração
\end{tabular}
parede.

Tabela 22. Comprimento, largura, espessura, diâmetro do lume e fração parede do clone A2 em função das doses de boro.

\begin{tabular}{llllll}
\hline Dose B $\left(\mathrm{kg} \mathrm{ha}^{-1}\right)$ & $\mathrm{C}^{*}(\mathrm{~mm})$ & $\mathrm{L}(\mu \mathrm{m})$ & $\mathrm{E}(\mu \mathrm{m})$ & $\mathrm{DL}(\mu \mathrm{m})$ & $\mathrm{FP}(\%)$ \\
\hline
\end{tabular}

Clone A2

\begin{tabular}{cccccc}
0 & 0,963 & 19,92 & 4,10 & 11,73 & 41 \\
0,5 & 0,960 & 20,25 & 4,25 & 11,75 & 42 \\
1 & 0,993 & 19,96 & 4,15 & 11,67 & 42 \\
2 & 0,955 & 19,42 & 4,15 & 11,13 & 43 \\
4 & 0,955 & 20,52 & 4,27 & 12,00 & 42 \\
8 & 0,915 & 19,69 & 4,18 & 11,34 & 42 \\
\hline C = comprimento; $\mathrm{L}=$ largura; $\mathrm{E}=$ = espessura da parede; $\mathrm{DL}=$ diâmetro do lume; FP = fração \\
parede.
\end{tabular}

\subsection{Resistência à geada}

Em relação a resistência à geada, foi observado efeito somente das doses de boro (Figura 11). A ausência de boro conferiu as árvores uma baixa resistência à ação da geada. $A$ dose de $1 \mathrm{~kg}$ de $B$ ha-1 permitiu uma maior resistência quando comparada a testemunha, não havendo diferença entre essa dose e as de 0,$5 ; 2 ; 4$ e $8 \mathrm{~kg}$ de $\mathrm{B} \mathrm{ha}{ }^{-1}$. 
Resultados semelhantes foram encontrados por Cooling \& Jones (1970) em plantios de eucaliptos, relacionando a interação boro e adubação NPK. Os tratamentos com omissão de boro foram os mais afetados pela geada em comparação aos tratamentos que receberam adubação boratada. Os autores admitiram que, para as condições do experimento, a presença de boro assegurou significativamente menor dano causado pela geada. Porém, não há nenhuma evidência que indique se a adição ou não de boro aumentaria a resistência à geada em locais onde este elemento não é realmente deficiente.

O efeito da geada nas plantas é decorrente do congelamento dos líquidos presentes nos espaços intercelulares, havendo ruptura de membranas por compressão e extravasamento irreversível do citoplasma (Higa et al., 1995). O fato da aplicação de boro ter proporcionado maior resistência aos efeitos da geada pode estar ligado ao papel do boro na formação da parede celular e na síntese de lignina. O desenvolvimento estrutural anormal da parede celular em condição de deficiência pode ocasionar uma diminuição drástica da plasticidade da parede celular (Dell \& Huang, 1997). Assim as plantas adubadas com boro teriam uma parede celular mais estruturada e lignificada conferindo uma maior resistência ao colapso provocado pelo congelamento de líquidos nos espaços intercelulares.

Em relação aos clones, estes apresentaram comportamento similar, não havendo diferença significativa entre eles. Tais resultados também foram observados por Lisbão Júnior (1980) em procedências de $E$. dunnii adubadas com NPK + Ca e Mg e as combinações PK + Ca e Mg; NK + Ca e Mg; NP + Ca e Mg; NPK e a ausência de adubação. O autor concluiu que as procedências apresentaram alta resistência à geada, entretanto não houve diferenças de comportamento entre elas. As avaliações foram realizadas aos 3 meses após a ação da geada, quando foi registrada temperatura de $-2,5^{\circ} \mathrm{C}$. 


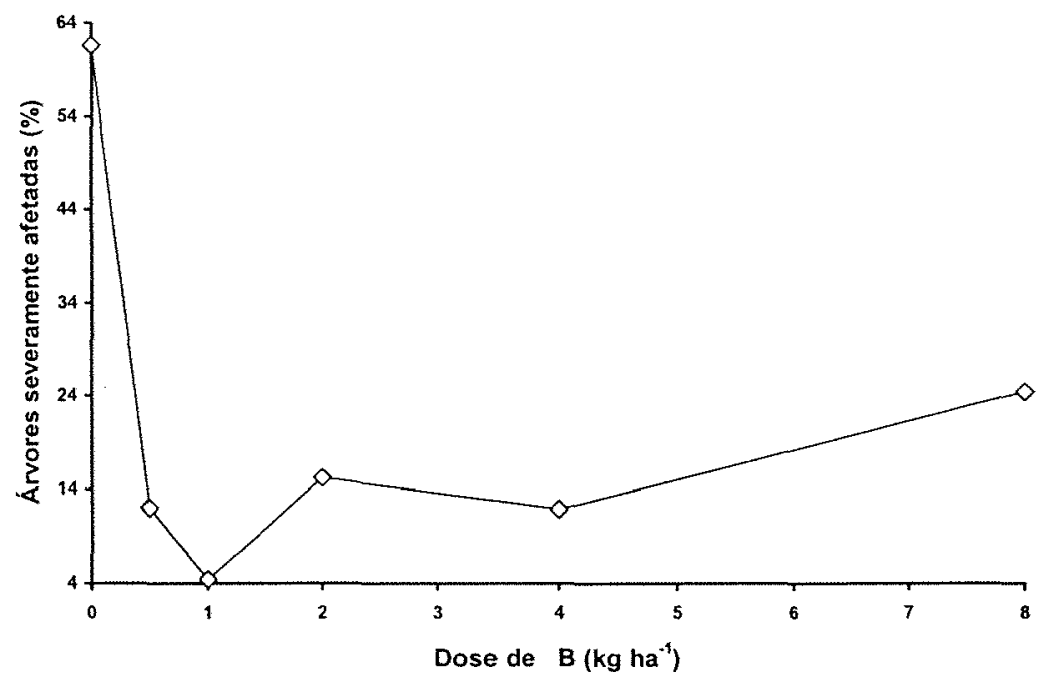

Figura 11 - Porcentagem de árvores afetadas pela geada em função das doses de boro aplicadas.

\subsection{Qualidade do fuste}

Em relação a qualidade do fuste não foi observado efeito das doses de boro e da interação dose $x$ clone. Houve diferença significativa somente entre os clones, sendo que o clone A2 apresentou maior porcentagem de árvores bifurcadas e trifurcadas em relação ao clone A1. A taxa de mortalidade do clone A2 foi maior que a do clone $A 1$, entretanto não foi observada diferença significativa (Tabela 23).

Tabela 23. Qualidade do fuste dos clones de E. grandis aos 12 meses de idade.

\begin{tabular}{ccccc}
\hline & \multicolumn{4}{c}{$\%$ árvores } \\
Clone & Normais & Bifurcada & Trifurcada & Morta \\
\hline A1 & $92,8 \mathrm{a}$ & $4,1 \mathrm{~b}$ & $0,55 \mathrm{~b}$ & $2,5 \mathrm{a}$ \\
A2 & $78,2 \mathrm{~b}$ & $13,8 \mathrm{a}$ & $2,9 \mathrm{a}$ & $5,1 \mathrm{a}$ \\
\hline
\end{tabular}

Médias seguidas de mesma letra não diferem entre si pelo teste de Tukey ao nivel de $5 \%$ de probabilidade. 


\section{CONCLUSÕES}

Para as condições em que foi realizado o experimento, as principais conclusões foram:

1. Os clones responderam de maneira diferenciada à aplicação de boro para a produção em volume. Os maiores ganhos foram obtidos para o clone $A 1$, aos 12 e 24 meses de idade.

2. A faixa adequada de boro nas folhas diagnóstico variou em função dos clones e da idade. O nível crítico de boro nas folhas diagnóstico foi de $35 \mathrm{mg}$ de $B \mathrm{~kg}^{-1}$ para o clone $\mathrm{A} 1$, aos 12 meses de idade. Aos 24 meses de idade o nível crítico para o clone $A 1$ foi de $18 \mathrm{mg}$ de $B$ $\mathrm{kg}^{-1}$ e para o clone $\mathrm{A} 2$ foi de $16 \mathrm{mg}$ de $\mathrm{B} \mathrm{kg}{ }^{-1}$.

3. A aplicação de $1 \mathrm{~kg}$ de $\mathrm{B} \mathrm{ha}{ }^{-1}$ foi suficiente para garantir o desenvolvimento das árvores até os 24 meses.

4. As doses de boro não tiveram efeito significativo sobre a densidade e as características anatômicas da madeira dos clones de $E$. grandis, aos 24 meses de idade. 


\section{REFERÊNCIAS BIBLIOGRÁFICAS}

ALBINO, J.C.; TOMAZELLO FILHO, M. Crescimento e densidade básica da madeira em 12 espécies de eucalipto. Boletim de Pesquisa Embrapa CPAC, n.25, p.1-46, 1984.

ALBINO, J.C.; TOMAZELLO FILHO, M. Variação da densidade básica da madeira e produtividade de Eucalyptus spp. Boletim de Pesquisa Embrapa CPAC, n.26, p.1-46, dez. 1985.

ANDRADE,A.M. de; VITAL, B.R.; BARROS, N.F. de; LUCIA, R.M.D.; CAMPOS, J.C.C.; VALENTE, O.F. Efeitos da fertilização mineral e da calagem do solo na produção e na qualidade da madeira do eucalipto. Revista Árvore, v.18, n.1, p.69-78, 1994.

ASSOCIAÇÃO BRASILEIRA DE CELULOSE E PAPEL. Distribuição geográfica da produção em toneladas. Relatório Estatístico BRACELPA 2000. São Paulo, 2000, p.204-205..

ASSOCIAÇÃO NACIONAL DOS FABRICANTES DE PAPEL E CELULOSE. SÃO PAULO. Relatório estatístico florestal. São Paulo, 1996. 60p.

BALLONI, E.A. Deficiência de boro em povoamentos florestais implantados. Boletim Informativo IPEF, v.5, n.14, p.49-65, maio 1977. 
BALLONI, E.A. Efeitos da fertilização mineral sobre o desenvolvimento do Pinus carbaea Morelet var. bahamensis (Guiseb) Barret e Golfari em solo cerrado do Estado de São Paulo. Piracicaba, 1984. 110 p. Dissertação (Mestrado) Escola Superior de Agricultura "Luiz de Queiroz", Universidade de São Paulo.

BARRICHELO, L.E.G.; FOELKEL, C.E.B. Processo nitrico-acético para maceração de madeiras. Silvicultura, v.28, p.732-733, 1983.

BARROS, N.F.; NOVAIS, R.F.; NEVES, J.C.L. Fertilização e correção do solo para o plantio de eucalipto. In: BARROS, N.F.; NOVAIS, R.F. (Ed.). Relação solo-eucalipto. Viçosa: Ed. Folha de Viçosa, 1990. cap. 4, p.127-186.

BELLOTE, A.F.J. Nährelementversorgung und wuchsleistung von gedüngten Eucalyptus grandis - plantagen im cerrado von São Paulo. (Resumo em português) Freiburg, 1990. 166p. Tese (Doutorado) - Universitat Freiburg.

BENEDETTI, V. O uso de boro em plantações florestais da Ripasa. In: SIMPÓSIO SOBRE O USO DO BORO EM FLORESTAS DE EUCALIPTO, 2., Piracicaba. 1998. Anais. Piracicaba: IPEF; ESALQ, 1999. p.189-214.

BRASIL, M.A.B. Variação da densidade básica da madeira de Eucalyptus propinqua Deane ex Maiden em função do local e do espaçamento. Piracicaba, 1972. 75p. Dissertação (Mestrado) - Escola Superior de Agricultura "Luiz de Queiroz", Universidade de São Paulo.

BRITO, J.O. Influência da adubação mineral nas características dos anéis de crescimento da madeira de Pinus caribaea var. bahamensis. Piracicaba, 1985. 113p. Tese (Doutorado) - Escola Superior de Agricultura "Luiz de Queiroz", Universidade de São Paulo. 
BROWN, P.H.; HU, H. Phloem mobility of boron is species dependent: evidence for phloem mobility in sorbitol-rich species. Annals of Botany, v.77, p.497$505,1996$.

BROWN, P.H.; SHELP, B.J. Boron mobility in plants. Plant and Soil, v.193, n. 1/2, p.85-101, 1997.

CANNON, P.G. Fourth results of forest fertilization with NPK, calfos and bórax on na Andept soil. Research Report Investigacion Forestal, v.68, p.10, 1981.

COHEN, M.S.; LEPPER Jr., R. Effect of boron on cell elongation and division in squash roots. Plant Physiology, v.59, n.5, p.884-887,1977.

COUTINHO, J.; BENTO, J.; VALE, R.; RAFAEL, J. Efeito do boro em Eucalyptus globulus no norte e centro interiores de Portugal. Vila Real: CEDR, SOPORCEL, 1995. 31p.

COOLING, E.N.; JONES, B.E. The importance of boron and NPK fertilizers to Eucalyptus in the sourthern province, Zambia. East African Agricultural and Forestry Journal, v.36, p.103-120, 1970.

DELL, B.; MALAJACZUK, N. Boron deficiency eucalypt in China. Canadian Journal of Forest Research, v. 24, p.2409-2416, 1994.

DELL, B.; BROWN, P.H.; BELL,R.W. Physiological response of plants to low boron. Plant and Soil, v.193, p. 103-120, 1997. 
DOWNES, G.M.; RAYMOND, C.A. Variation in wood density in plantation eucalypts. In: DOWNES, G.M.; HUDSON, I.L.; RAYMOND, C.A.; DEAN, G.H.; MUNIERI, A. Sampling plantation eucalypts for wood and fibre properties. Melbourne: CSIRO, 1997. p. 88-95.

DRUGGER, W.M. Boron in plant metabolism. In: LÄUCHLI, A.; BIELESKI, R.L., (Ed.) Inorganic plant nutrition. Berlin:Springer-Verlag, 1983. cap. 5, p.625650. (Encyclopedia of Plant Physiology. New Series, v.15B).

FERREIRA, M.; KAGEYAMA,P.Y. Melhoramento genético da densidade da madeira de eucalipto. Boletim Informativo IPEF, v.6, n.20, p.1-14, nov.1978.

FERREIRA, C.A.; FREITAS, M.; FERREIA, M. Densidade básica da madeira de plantações comerciais de eucaliptos, na região de Mogi-Guaçu - SP. IPEF, n.18, p.106-117, 1979.

FOELKEL, C.E.B.; BARRICHELO, L.E.G.; MILANEZ, A.F. Estudo comparativo das madeiras de Eucalyptus saligna, Eucalyptus paniculata, Eucalyptus citriodora, Eucalyptus maculata e Eucalyptus terenticornis para a produção de celulose sulfato. IPEF, n.10, 17-37, 1975.

FOELKEL, C.E.B.; MORA, E.; MENOCHELLI, S. Densidade básica: sua verdadeira utilidade como índice de qualidade da madeira de eucalipto para produção de celulose. O Papel, v.53, n.5, p.35-40, maio 1992. 
FONSECA, S.; MALUF, J.L.P.; OLIVEIRA, A.C. Adubação de Eucalyptus camaldulensis com boro e zinco em solos do cerrado na região de Brasilândia-Minas Gerais. In: CONGRESSO FLORESTAL BRASILEIRO, 6. Campos do Jordão, 1990. Anais. São Paulo: SBS; SBEF, 1990. v.3, p.403406.

GARCIA, H.C.; SANTOS, P.E.T. Danos ocasionados pelas geadas no Estado de São Paulo. Florestar Estatístico, v.2, n.6, p.23-24, nov./dez. 1995.

GIOVANETTI, R.Z. O uso de boro na Lwarcel Celulose e Papel Ltda. In: SIMPÓSIO SOBRE O USO DO BORO EM FLORESTAS DE EUCALIPTO, 2., Piracicaba. 1998. Anais. Piracicaba: IPEF; ESALQ, 1999. p.172-188.

GONÇALVES, J.L.M. Recomendações de adubação para Eucalyptus, Pinus e espécies típicas da Mata Atlântica. Documentos Florestais, v.15, p.1-23, 1995.

GUPTA, V.C. Boron nutrition of crops. Advances in Agronomy, v.31, p.273$307,1979$.

HEWITT, E.J.; SMITH, T.A. Plant mineral nutrition. London: The English Universities 1975. 298p.

HIGA, A.R.; GARCIA, C.H.; SANTOS, E.T. Geadas, prejuizos à atividade florestal. Silvicultura, v.16, n.59, p.40-43, jan./fev. 1995.

HIGA, R.C.V. Efeito do ABA (Ácido Abscísico) na resistência a geada de Eucalyptus viminalis Labill. In: CONGRESSO FLORESTAL BRASILEIRO, 7., Curitiba, 1993. Anais. São Paulo: SBS; SBEF, 1993. v.1, p.113-116. 
HIGGS, M.L.; RUDMAN, The effects of fertilizing and thinning on wood properties of Eucalypts regnans. Appita, v.27, n.1, p.51-55, 1973.

JACOB, W.S.; BALLONI, E.A. Efeitos da fertilização na qualidade da madeira. Boletim Informativo IPEF, v.6, n.20, p.1-13, nov. 1978.

JALKANEN, R.E.; REDFERN, D.B.; SHEPPARD, L.J. Nutrient deficits increases frost hardiness in Sitka spruce (Picea sitchensis) needles. Forest Ecology and Management, v.107, p.191-201, 1998.

JORGE, F.; PEREIRA, H. Influência da Silvicultura na Qualidade da Madeira. Revista Florestal, v.11, n.2, p.27-31, jul./dez. 1998.

LEWIS, D.H. Boron, lignification and the origin of vascular plants - a unified hypothesis. New Phytologist, v.84, p.209-229, 1980.

LIMA, J.T.; ROSADO, S.C.S.; OLIVEIRA, A.D. Variação da densidade da madeira de Eucalyptus grandis, Eucalyptus terenticornis e Eucalyptus camaldulensis no sentido longitudinal dos caules. Ciência e Prática, v.16, n.1, p.1213-1217, jan./mar. 1992.

LIMA FILHO, O.F. A importância do boro no cafeeiro. In: REUNIÃO TÉCNICA SOBRE O USO DE BORO EM RESPOSTA A: PLANTAÇÕES FLORESTAIS, 1., Piracicaba. 1998. Anais. Piracicaba: IPEF,1998. p.30-48.

LISBÃO JÚNIOR, L. O efeito da geada e o comportamento inicial de três procedências de Eucalyptus dunni Maiden, em ensaio conjugado de miniespaçamentos e adubação. Boletim de Pesquisa Florestal, v.1, p.28-49, dez. 1980. 
LISBÃO JÚNIOR, L. Comparação entre dois métodos de avaliação e análise dos danos de geada em mudas de Eucalyptus viminalis Labill. Boletim de Pesquisa Florestal, v.13, p.25-33, dez. 1986.

MALAVOLTA, E. Elementos minerais . In: MALAVOLTA, E. Elementos de nutrição mineral de plantas. São Paulo: Editora Agronômica Ceres, 1980. cap.6. p. 104-219.

MALAVOLTA, E.; KLIEMANN, H.J. Desordens nutricionais do cerrado. Piracicaba: Potafos, 1985. 136p.

MALAVOLTA, E.; VITTI, G.C.; OLIVEIRA, S.A. Funções, princípios, métodos e técnicas de avaliação do estado nutricional. In: MALAVOLTA, E.; VITTI, G.C.; OLIVEIRA, S.A. (Ed.) Avaliação do estado nutricional das plantas: princípios e aplicações. Piracicaba: Associação Brasileira para a Pesquisa da Potassa e do Fosfato, 1989. cap. 4/5, p.31-129.

MALAVOLTA, E.; VITTI, G.C.; OLIVEIRA, S.A. Funções. In: MALAVOLTA, E.; VITTI, G.C.; OLIVEIRA, S.A. Avaliação do estado nutricional das plantas: princípios e aplicações. 2.ed. Piracicaba: Associação Brasileira para a Pesquisa da Potassa e do Fosfato, 1997a. cap. 4, p. 55-105.

MALAVOLTA, E.; VITTI, G.C.; OLIVEIRA, S.A. Principios, métodos e técnicas de avaliação do estado nutricional. In: MALAVOLTA, E.; VITTI, G.C.; OLIVEIRA, S.A. Avaliação do estado nutricional das plantas: princípios e aplicações. 2.ed. Piracicaba, Associação Brasileira para a Pesquisa da Potassa e do Fosfato, 1997b. cap. 5. p. 115-217. 
MALAVOLTA, E.; VITTI, G.C.; OLIVEIRA, S.A. Metodologia para análise de elementos em material vegetal. In: MALAVOLTA, E.; VITTI, G.C.; OLIVEIRA, S.A. Avaliação do estado nutricional das plantas: princípios e aplicações. 2.ed. Piracicaba, Associação Brasileira para a Pesquisa da Potassa e do Fosfato, 1997c. cap. 6. p. 231-305.

MARSCHNER, H. Mineral nutrition of higher plants. San Diego: Academic Press, 1986. 674p.

MATOH, T.; ISHIGAKI, K.I.; MIZUTANI, M.; MATSUNAGA, M; TAKABE, K. Boron nutrition of cultured tabacco BY -2 cells. I. Requeriment for intracellular localization of boron and selection of cells that tolerant low levels of boron. Plant Cell Physiology, v.33, p.1135-1141, 1992.

MELLO,H.A. Efeitos da adulação mineral sobre as qualidades da madeira. Piracicaba: IPEF; ESALQ, 1968. 16p. (Relatório Técnico)

MIGLIORINI, A.J. Variação da densidade básica da madeira de Eucalyptus grandis Hill ex Maiden em função de diferentes níveis de produtividade da floresta. Piracicaba, 1986. 80 p. Dissertação (Mestrado) - Escola Superior de Agricultura "Luiz de Queiroz", Universidade de São Paulo.

MORA, A.L.; GARCIA, C.H. A cultura do eucalipto no Brasil. São Paulo: SBS, 2000.112p.

MORAES, E.J. O uso de boro em plantios de eucaliptos na região norte e noroeste de Minas Gerais. In: SIMPÓSIO SOBRE O USO DO BORO EM FLORESTAS DE EUCALIPTO, 2., Piracicaba. 1998. Anais. Piracicaba: IPEF; ESALQ, 1999. p.2-46. 
NOVELINO, J.O.; NEVES, J.C.L.; BARROS, N.F. de; NOVAIS, R.F. de; MUNIZ, A.S. Efeito de níveis de boro em solução nutritiva no crescimento de Eucalyptus spp. Revista Árvore, v.6, n.1, p.45-51, jan./jun. 1982.

POLLARD, A.S.; PARR, A.J.; LOUGHMAN, B.C. Boron in relation to membrane function in higher plants. Journal of Experimental Botany, v.28, n.105, p.831-841, 1977.

REAL, P. Daños por falta de boro en el Sureste del Uruguay. Florestal: Revista de la Sociedade de Productres Forestalis, v.5, n.15, p.25-27, dez. 2000.

ROCHA FILHO, J.V.C.; HAAG, H.P.; OLIVEIRA, G.D. Deficiência de macronutrientes, boro e ferro em Eucalyptus urophylla. Anais da Escola Superior de Agricultura "Luiz de Queiroz", v.35, p.19-355, mar. 1978.

SAS INSTITUTE. SAS/STAT: software; version 6. Cary, 1990. 50 p.

SAVORY, B.M. Boron deficiency in Eucalyptus in Northern Rhodesia. Empire Forest Review, v.41, p.118-125, 1962.

SGARBI, F.; SIVEIRA, R.L.V.A. Resposta do Eucalyptus à aplicação de boro e potássio na região de Três Marias - MG. In: SIMPÓSIO SOBRE O USO DO BORO EM FLORESTAS DE EUCALIPTO, 2., Piracicaba. 1998. Anais. Piracicaba: IPEF; ESALQ, 1999. p.89-105.

SGARBI, F.; SILVEIRA, R.L.V.A.; BRITO, J.O. Características químicas e físicas e dimensões das fibras da madeira juvenil do híbrido Eucalyptus grandis x Eucalyptus urophylla, cultivado na omissão de macronutrientes e boro em solução nutritiva. Revista Árvore, v.24, n.3, p.323-331, 2000. 
SHIMOYAMA, V.R.S., BARRICHELO, L.E. Importância da adubação na qualidade da madeira e celulose. In: SIMPÓSIO SOBRE ADUBAÇÃO E QUALIDADE DE PRODUTOS AGRÍCOLAS, 1., Ilha Solteira, 1989. Anais. Ilha Solteira: UNESP; POTAFOS, 1989. 1v, cap. 9. p.1-15.

SIDDIQUI, K.M. Influence of fertilization on the ultrastructure and chemical composition of wood. Syracuse, 1972. 161p. Thesis (Ph.D.) -University of Syracuse.

SILVEIRA, R.L.V.A. Uso de boro em Eucalyptus no Brasil. In: REUNIÃO TÉCNICA SOBRE O USO DE BORO EM PLANTAÇÕES FLORESTAIS, 1., Piracicaba. 1998. Anais. Piracicaba: IPEF; ESALQ, 1998. p.30-48.

SILVEIRA, R.L.V.A. Efeito do potássio no crescimento, nas concentrações dos nutrientes e nas características da madeira juvenil de progênies de Eucalyptus grandis W. Hill ex Maiden cultivadas em solução nutritiva. Piracicaba, 2000. 169 p. Tese (Doutorado) - Escola Superior de Agricultura "Luiz de Queiroz", Universidade de São Paulo.

SILVEIRA, R.L.V.A.; GONÇALVES, A.N.; KRÜGNER, T.L. Estado nutricional de Eucalyptus citriodora Hook cultivado sob diferentes doses de boro e sua relação com a agressividade de Botryosphoeria ribis. Scientia Forestalis, n.53, p.57-70, jun. 1998.

SILVEIRA, R.L.V.A.; SILVEIRA, R.I.; KRUGNER, T.L.; BRANCO, E.F. The role of nutrients in Eucalyptus citriodora through leaf fertilization and its relation to the appearance of nutritional disturbs. In: PROCEEDINGS INTERNATIONAL CONGRESS ON SOILS OF TROPICAL FOREST ECOSYSTEMS. CONFERENCE ON FOREST SOILS 3., Samarinda: Mulawarman University Press, 1995, p. 262-268. 
SILVEIRA, R.L.V.A.S.; TAKAHASHI, E.N.; SGARBI, F.; BRANCO, E.F. Sintomas de deficiência de macronutrientes e boro em hibrido de Eucalyptus grandis $x$ Eucalyptus urophylla em solução nutritiva (compact disk). In: CONGRESSO LATINO AMERICANO DE CIENNCIA DO SOLO, 13., Anais. Águas de Lindóia: Sociedade Americana de Ciência do Solo, 1996.

SOUZA, V.R.; CARPIM, M.A.; BARRICHELO, L.E.G. Densidade básica entre procedências, classes de diâmetro e posição em árvores de Eucalyptus grandis e Eucalyptus saligna. IPEF, n.33, p.63-72, 1986.

STAPE, J.L. Potencial de crescimento do Eucalyptus grandis numa Areia Quartzosa do Estado de São Paulo. In: REUNIÃO BRASILEIRA DE FERTILIDADE DO SOLO E NUTRIÇÃO DE PLANTAS, 20., Piracicaba, 1992. Anais. Piracicaba: Sociedade Brasileira de Ciência do Solo, 1992. p.172-173.

STONE, E.L. Boron deficiency and excess in forest trees: a review. Forest Ecology and Management, v. 37, p. 49-75, 1990.

SUBRAHMANYAM, S.V. Effect of nitrogen and phosphorus on fibre morphology of Eucalyptus grandis. Advances in Forestry Research in India, v.1, p.207215, 1988.

SUTINEN, M.L.; PALTA, J.P.; REICH, P.B. Seasonal differences in freezing stress resistance of needles of Pinus nigra and Pinus resinosa: evaluation of the electrolyte leakage method. Tree Physiology, v.11, p.241-254, 1992.

TEIXEIRA, M.L.; MENDES, L.M. Correlação entre densidade básica e componentes químicos da madeira de Pinus oocarpa. O Papel, v.56, n.11, p.37-40, nov. 1995. 
TOKESHI, F.; GUIMARÃES, R.F.; TOMAZELLO FILHO, M. Deficiência de boro em Eucalyptus em São Paulo. Summa Phytopathologica, v.2, n.2, p.122-126, 1976.

TOMAZELLO FILHO, M. Variação radial da densidade básica e da estrutura anatômica da madeira de Eucalyptus saligna e Eucalyptus grandis. IPEF, n.29, p. 37-45, 1985.

TREVISAN, R. Atuação de concentrações de boro na morfogênese de Eucalyptus urophylla cultivados in vitro. Piracicaba, 2000. 75 p. Dissertação (Mestrado) - Escola Superior de Agricultura "Luiz de Queiroz", Universidade de São Paulo.

VAIL, J.W.; CALTON, W.E.; STRANG, R.M. Dieback of Wattle: boron deficiency. Empire African Agriculture Journal, v.23, n.2, p.100-103, 1957.

VALE, A.T.; MOURA, V.P.G.; MARTINS, I.S.; REZENDE, D.C.A. Densidade básica média em função da profundidade de penetração do pino do "pilodyn" e da classe diamêtrica e variação axial da densidade básica em Eucalyptus grandis Hill ex Maiden. Revista Árvore, v.19, n.1, p.80-91, 1985.

VALE, R.; COUTINHO, J.; BENTO, J. A deficiência de boro em Eucalyptus numa região de Trás-os-Montes. Vila Real:UTAD, 1995. p.1-7.

VETORAZZO, S.C. Efeito de fatores do solo e de genótipos no crescimento, nutrição e atividade da fosfatase ácida em clones de Eucalyptus grandis Hill ex Maiden. Piracicaba, 1989. 115 p. Dissertação (Mestrado) - Escola Superior de Agricultura "Luiz de Queiroz", Universidade de São Paulo. 
VITAL, B.R. Reflexos da fertilização mineral na qualidade e na utilização da madeira. In: BARROS, N.F.; NOVAIS, R.F. (Ed.) Relação solo-eucalipto. Viçosa: Editora Folha de Viçosa, 1990. cap.9, p.323-328.

WILKINS, A.P. Influence of silvicultural treatment on growth and wood density of Eucalyptus grandis grown on a previous pasture site. Australian Forestry, v. 53, n. 3, p.168-172, 1990.

WILKINS, A.P.; HORNE, R. Wood-density variation of young plantation grown Eucalyptus grandis in response to silvicultural treatments. Forest Ecology and Manegement, v.40, p.39-50, 1991.

WILKINS. A.P.; KITAHARA, R. Silvicultural treatments and associeted grown rates, growth strains and wood properties in 12,5 year old Eucaliptus grandis. Australian Forestry, v.54, p.99-104, 1991. 